Effigy Vessel Documentation, Caddo Collections at the Texas Archeological Research Laboratory at The University of Texas at

\title{
Austin
}

Timothy K. Perttula

Heritage Research Center, Stephen F. Austin State University

Robert Z. Selden Jr.

Heritage Research Center, Stephen F. Austin State University

Follow this and additional works at: https://scholarworks.sfasu.edu/ita

Part of the American Material Culture Commons, Archaeological Anthropology Commons, Environmental Studies Commons, Other American Studies Commons, Other Arts and Humanities Commons, Other History of Art, Architecture, and Archaeology Commons, and the United States History Commons

Tell us how this article helped you.

This Article is brought to you for free and open access by the Center for Regional Heritage Research at SFA ScholarWorks. It has been accepted for inclusion in Index of Texas Archaeology: Open Access Gray Literature from the Lone Star State by an authorized editor of SFA ScholarWorks. For more information, please contact cdsscholarworks@sfasu.edu. 


\section{Effigy Vessel Documentation, Caddo Collections at the Texas Archeological Research Laboratory at The University of Texas at Austin}

\section{Creative Commons License}

\section{(c) (1) \&}

This work is licensed under a Creative Commons Attribution-NonCommercial 4.0 International License 


\title{
Effigy Vessel Documentation, Caddo Collections at the Texas Archeological Research Laboratory at The University of Texas at Austin
}

\author{
Timothy K. Perttula and Robert Z. Selden Jr.
}
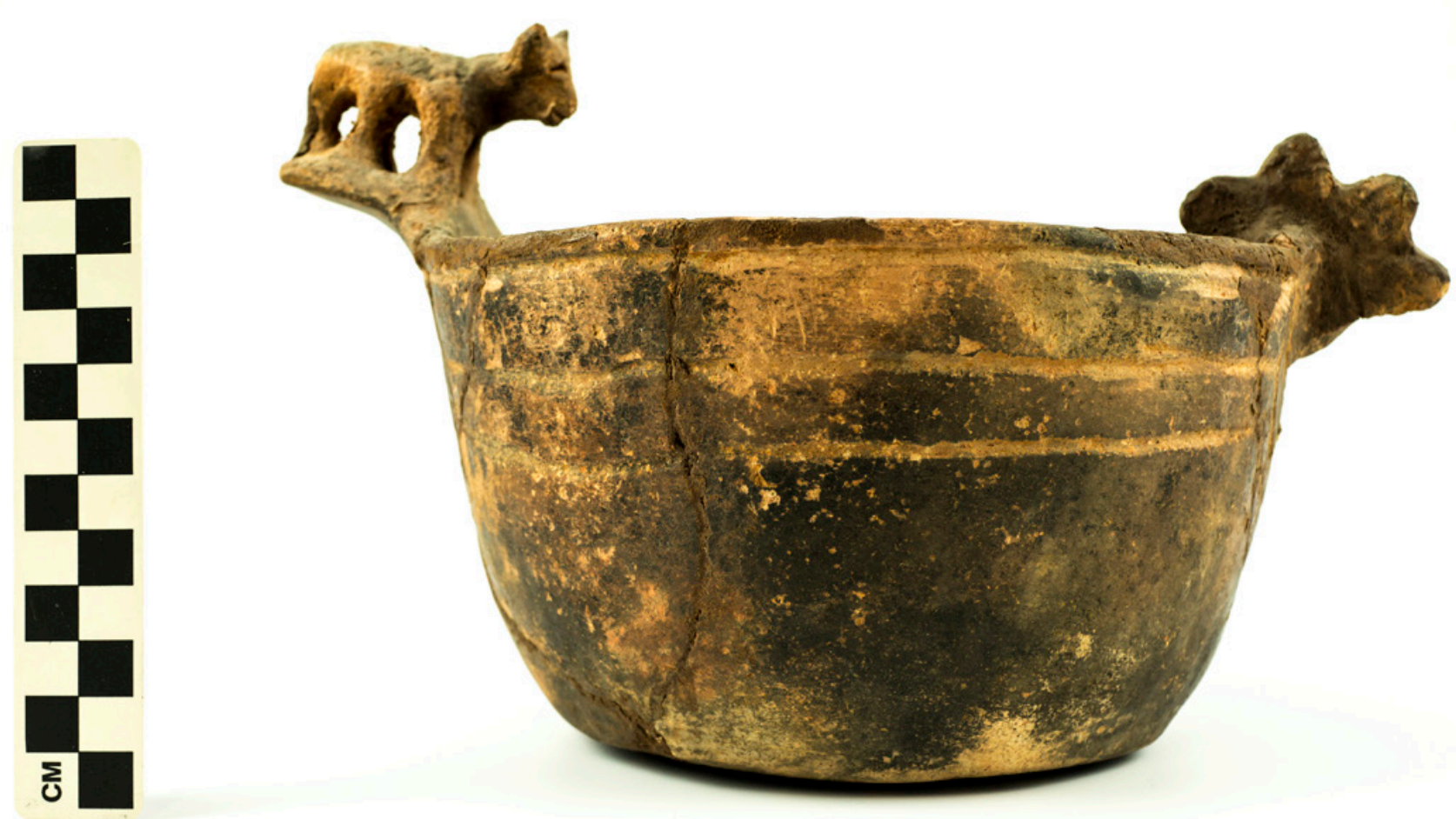

Special Publication No. 40

Friends of Northeast Texas Archaeology, Austin and Pittsburg 


\section{Friends of Northeast Texas Archaeology Editor, Timothy K. Perttula 10101 Woodhaven Dr. Austin, Texas 78753 tkp4747@aol.com}

\section{Friends of Northeast Texas Archaeology, Distribution, Bo Nelson, 344 CR 4154 \\ Pittsburg, Texas 75686 \\ RBoNelson@aol.com}

Cover art: Hood Engraved, var. Allen effigy vessel from the Pierce Freeman site (41AN34)

Copyright (C) 2015, Friends of Northeast Texas Archaeology

(Pittsburg and Austin) 


\section{Table of Contents}

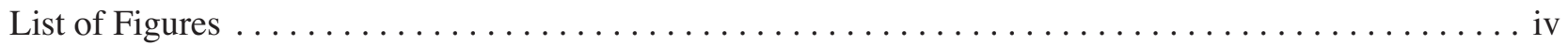

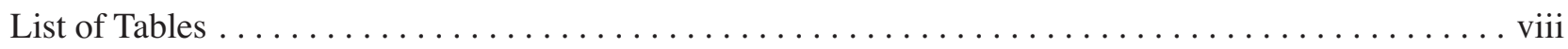

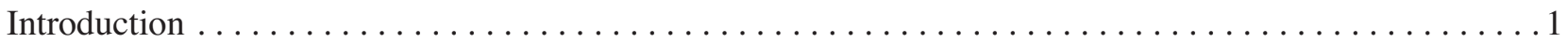

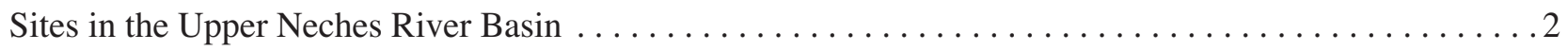

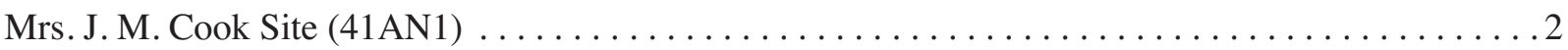

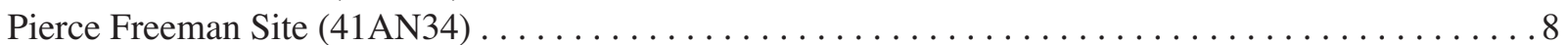

Jasper Tucker/Mrs. Joe Watkins Farm Site $(41$ AN44) $\ldots \ldots \ldots \ldots \ldots \ldots \ldots \ldots \ldots \ldots \ldots \ldots$

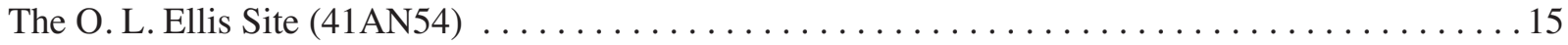

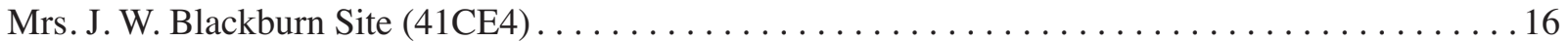

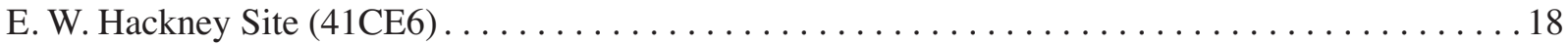

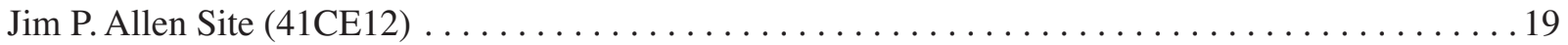

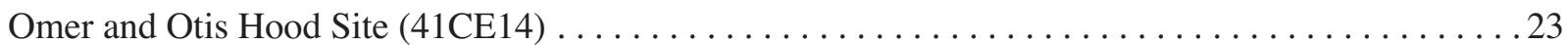

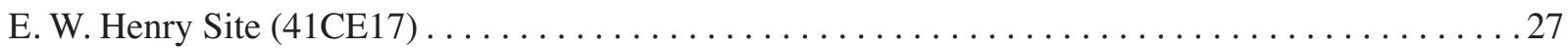

Big Cypress Creek Caddo Sites with Effigy Vessels $\ldots \ldots \ldots \ldots \ldots \ldots \ldots \ldots \ldots \ldots \ldots \ldots \ldots \ldots \ldots \ldots \ldots \ldots \ldots \ldots \ldots$

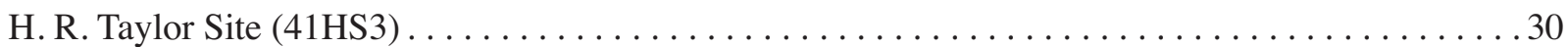

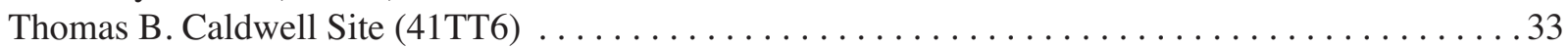

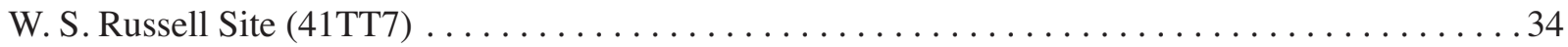

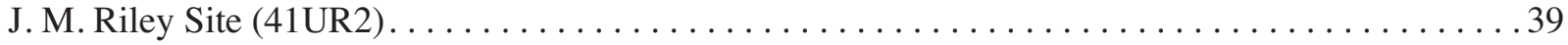

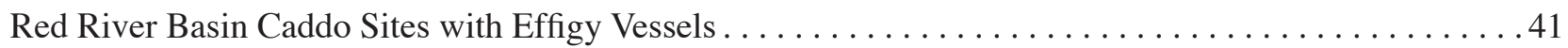

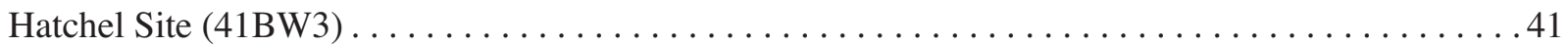

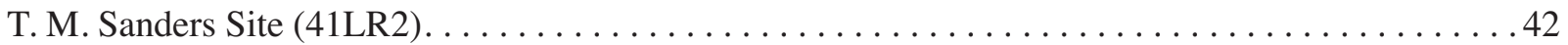

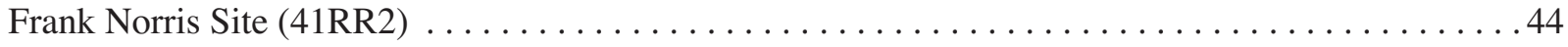

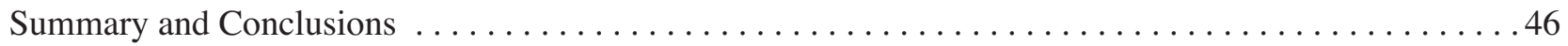

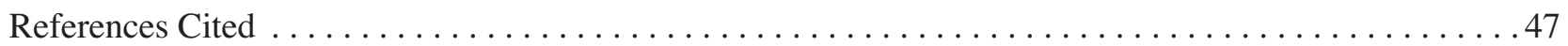




\section{List of Figures}

1. Location of East Texas sites mentioned in the text with effigy vessels $\ldots \ldots \ldots \ldots \ldots \ldots \ldots \ldots 1$

2. Distribution of Hood Engraved effigy vessels in the upper Neches River basin:

a, sites in the Neches and Angelina River basin; b, sites with Hood Engraved effigy vessels . . . . . 3-4

3. Hood Engraved, var. Allen effigy vessel from the Mrs. J. M. Cook site (41AN1) . . . . . . . . . 5

4. Hood Engraved, var. Cook effigy bowl from the Mrs. J. M. Cook site (41AN1) . . . . . . . . ...6

5. Hood Engraved, var. Hood effigy vessel from the Mrs. J. M. Cook site (41AN1) . . . . . . . . . . . 7

6. Hood Engraved, var. Allen effigy vessel from the Pierce Freeman site $(41 \mathrm{AN} 34) \ldots \ldots \ldots \ldots \ldots$

7. Hood Engraved, var. Hood effigy bowl (AN44-3) from the Jasper Tucker/ Mrs. Joe Watkins Farm Site $(41$ AN44) . . . . . . . . . . . . . . . . . . . . . . . . . . . . . 9

8. Hood Engraved, var. Hood effigy bowl (AN44-4) from the Jasper Tucker/

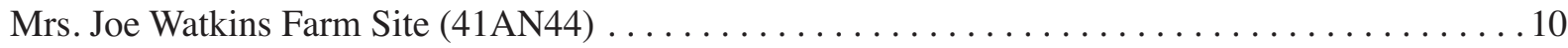

9. Hood Engraved, var. Hood effigy bowl (AN44-6) from the Jasper Tucker/

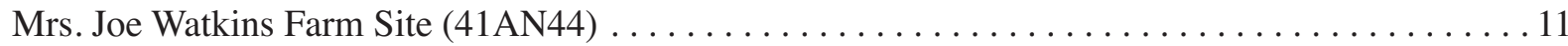

10. Hood Engraved, var. Hood effigy bowl (AN44-7) from the Jasper Tucker/

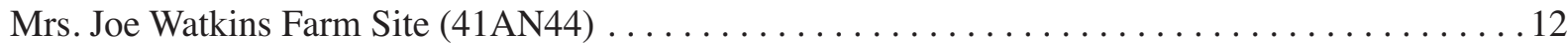

11. Hood Engraved, var. Hood effigy bowl (AN44-8) from the Jasper Tucker/ Mrs. Joe Watkins Farm Site $(41$ AN44) . . . . . . . . . . . . . . . . . . . . . . . . 13

12. Hood Engraved, var. Hood effigy bowl (AN44-14) from the Jasper Tucker/

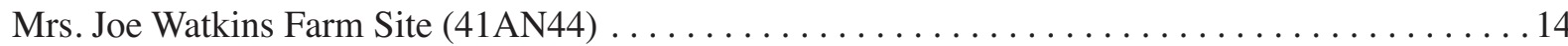

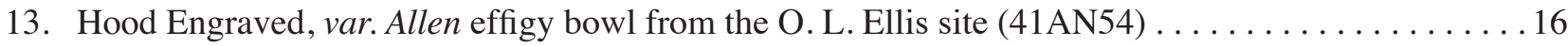

14. Hood Engraved, var. Hood effigy vessel from the Mrs. J. W. Blackburn site (41CE4) . . . . . . . . 17

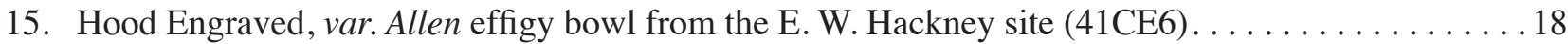

16. Hood Engraved, var. Hood effigy bowl (41CE12-8) from the Jim P. Allen site (41CE12) . . . . . . . 19

17. Hood Engraved, var. Allen effigy bowl (41CE12-169) from the Jim P. Allen site (41CE12) . . . . . 20

18. Hood Engraved, var. Allen effigy bowl (41CE12-176) from the Jim P. Allen site (41CE12) . . . . . 21

19. Hood Engraved, var. Allen effigy bowl (41CE12-181) from the Jim P. Allen site (41CE12) . . . . . 22

20. Hood Engraved, var. unspecified effigy vessel (41CE14-33) from the Omer and

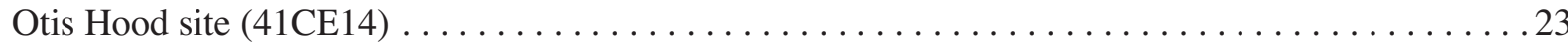

21. Hood Engraved, var. Hood effigy vessel (41CE14-47) from the Omer

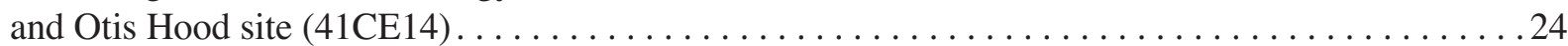

22. Hood Engraved, var. Hood effigy vessel (41CE14-77) from the Omer

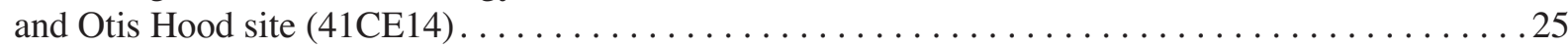

23. Hood Engraved, var. Hood effigy vessel (41CE14-118) from the Omer

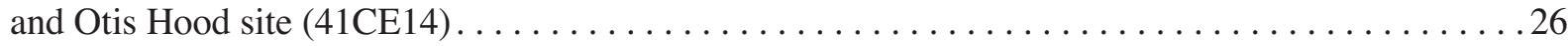


24. Hood Plain, var. unspecified effigy bowl (41CE17-19) from the E. W. Henry site (41CE17) . . . . 27

25. Poynor Engraved, var. $S$ carinated bowl with effigy tab tails from the E. W. Henry site (41CE17) . . 28

26. Hood Engraved, var. Hood effigy bowl (41CE17-31) from the E. W. Henry site . . . . . . . . . . . 29

27. Engraved-punctated effigy bowl (41HS3-468) from the H. R. Taylor site (41HS3) . . . . . . . . 31

28. Engraved effigy bowl (41HS3-731) from the H. R. Taylor site $(41 \mathrm{HS} 3) \ldots \ldots \ldots \ldots \ldots \ldots \ldots \ldots$

29. Hood Engraved, var. Hood effigy bowl from the Thomas B. Caldwell site (41TT6) . . . . . . . . .33

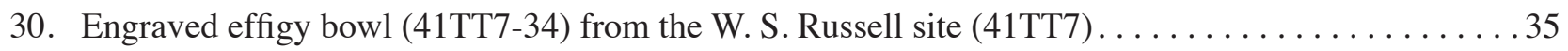

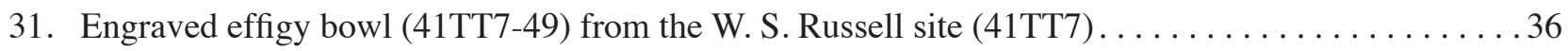

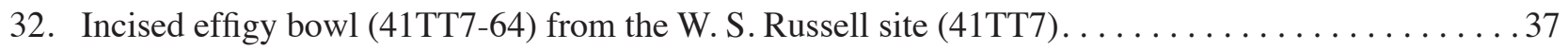

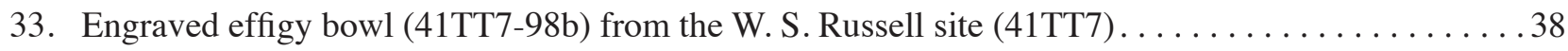

34. Engraved effigy bowl from the J. M. Riley site (41UR2) $\ldots \ldots \ldots \ldots \ldots \ldots \ldots \ldots \ldots \ldots \ldots \ldots \ldots \ldots \ldots \ldots$

35. Plain effigy bowl with a tab tail attachment from Village Plot 2 at the Hatchel site (41BW3) . . . . 42

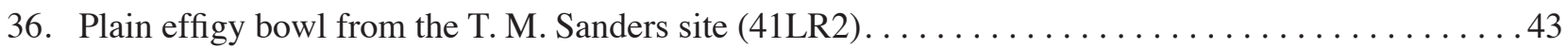

37. Engraved and appliqued effigy bowl from the Frank Norris site $(41 \mathrm{RR} 2) \ldots \ldots \ldots \ldots \ldots \ldots$ 


\section{Acknowledgments}

We thank the staff at the Texas Archeological Research Laboratory for their assistance in helping us complete this study and documentation of ceramic vessels in their collections. Photographs in this Special Publication were taken by Robert Z. Selden Jr., while the figures were prepared by Lance Trask and Sandy Hannum. 


\section{Introduction}

Ceramic vessels from ancestral Caddo sites in East Texas are diverse in form, size, manufacture, and decoration, both spatially and temporally. Variation in these attributes, including vessel form as well as any attachments, also "is connected with particular local and regional traditions" (Brown 1996:335). To both appreciate and understand the meaning of vessel form diversity in Caddo vessel assemblages in East Texas - or any other part of the much larger southern Caddo area-the consistent identification of different vessel forms and vessel shapes is crucial (Perttula 2015). The formal identification of the diverse vessel forms and vessel shapes, in conjunction with other vessel attributes, most notably decorative motifs and elements, present in Caddo vessel assemblages should contribute to delimiting the existence and spatial distribution of communities of Caddo potters that were sharing or not sharing ceramic practices and traditions in both short-term and long-term spatial scales, and illuminating small or expansive networks of social groups tied together through regional interaction.

In this study, the focus is on ceramic effigy vessels from Caddo sites in East Texas that are in the collections at the Texas Archeological Research Laboratory at The University of Texas at Austin (TARL) (Figure 1). Ceramic effigy vessels are a very rare vessel form found on Caddo sites, as they comprise about 1 percent of the more than 3100 Caddo vessels currently in the TARL collections.

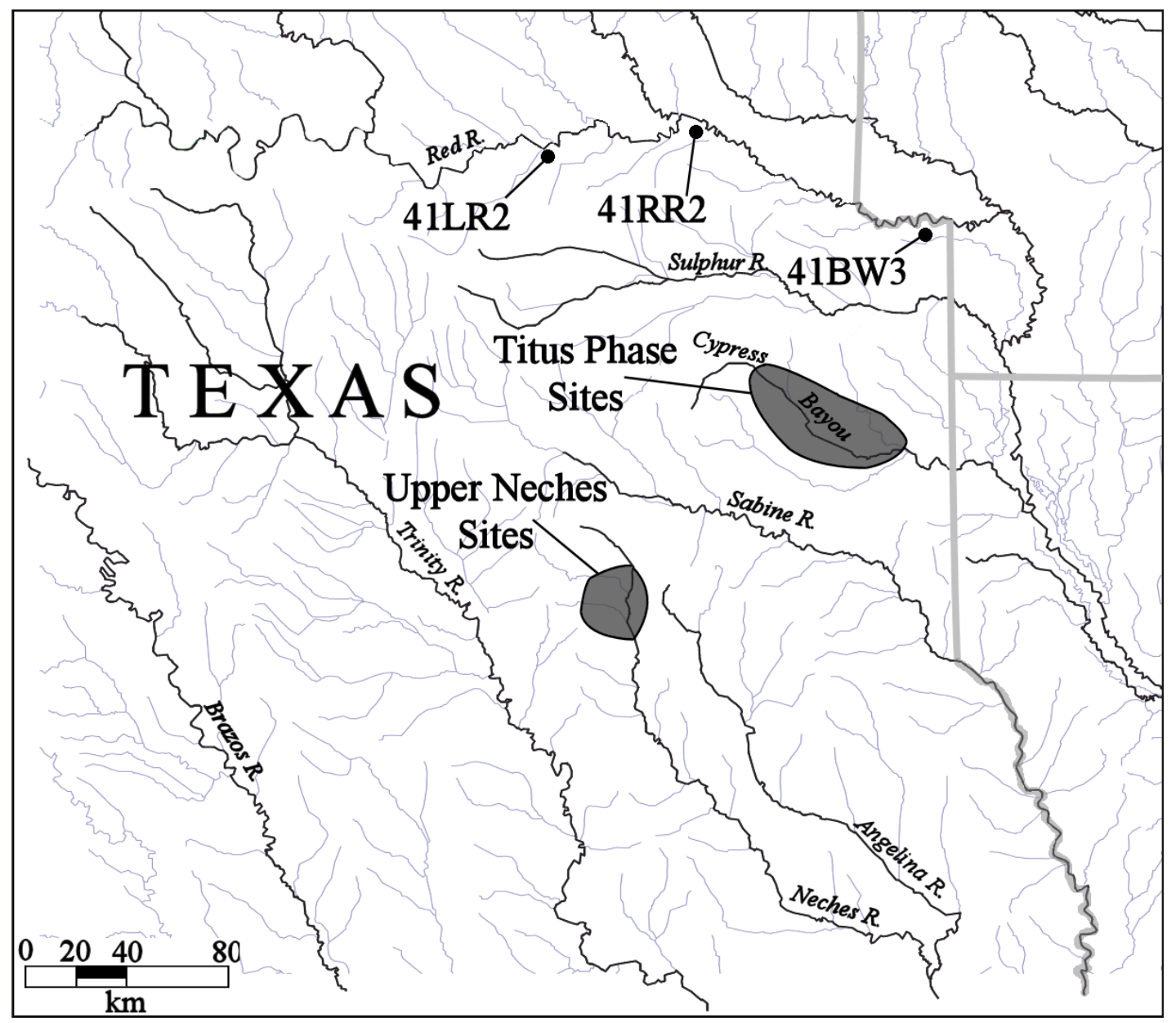

Figure 1. Location of East Texas sites mentioned in the text with effigy vessels. 
Three different effigy bowl shapes have been identified in East Texas Caddo vessel assemblages (Perttula 2015:Figure 8a-c). The differences primarily resolve around the character of the effigy head (both bird and abstract forms) as well as the nature of any other appendages, such as tab tails (Perttula 2015:Figure 8b) and tail riders (Perttula 2015:Figure 8a). The effigy bowls themselves are simple in form, with rounded body wall contours.

\section{Sites in the Upper Neches River Basin}

The majority of the Caddo effigy vessels found in East Texas come from ancestral Caddo sites of Frankston (ca. A.D. 1400-1650) and Allen phase (ca. A.D. 1650-1830) age in the upper Neches River basin. This is an area that was heavily populated by Caddo peoples, and there are now known many Caddo settlements and cemeteries preserved in the regional archaeological record (Figure 2a). Both Hood Engraved, var. Hood and Hood Engraved, var. Allen effigy vessels have been recovered from upper Neches River basin Caddo cemeteries (Figure 2b), and Hood Engraved, var. Hood vessels from Frankston phase contexts have a broader distribution in the basin than do the Hood Engraved, var. Allen effigy vessels with tail riders known from Allen phase cemeteries.

\section{Mrs. J. M. Cook Site (41AN1)}

The Mrs. J. M. Cook was excavated in 1931 by a UT crew (Jackson 1931). All six burials found at this sub-phase 2 Frankston phase (ca. A.D. 1480-1560) cemetery had associated vessels as funerary offerings. A total of 33 vessels are in the TARL collections from the site. They include 11 carinated bowls, one compound bowl, nine jars, eight bowls, and four bottles.

The vessels include both fine ware and utility ware types. The fine ware types are represented by Poynor Engraved carinated bowls and compound bowls (vars. Blackburn, Hood, Lang, var. Q, and var. $R$, see Perttula et al. 2011:Figures 6-64 and 6-65), Hood Engraved effigy bowls, Hume Engraved bottles. Utility vessels are represented by a Killough Pinched rattle bowl, Killough Pinched jars, Bullard Brushed jars, La Rue Neck Banded jar, and a Maydelle Incised jar.

SITE NO.: 41AN1

FEATURE: Burial E-2

VESSEL NO.: 41AN1-7

NON-PLASTICS: grog

VESSEL FORM: Effigy bowl with a direct rim and a rounded lip; effigy head (reconstructed bird head) on one side of the vessel and a tail rider (a four-legged animal with a tail) on the opposing side (Figure 3)

CORE COLOR: Undetermined

WALL THICKNESS: $7.8 \mathrm{~mm}$

INTERIOR SURFACE TREATMENT: smoothed EXTERIOR SURFACE TREATMENT: burnished 


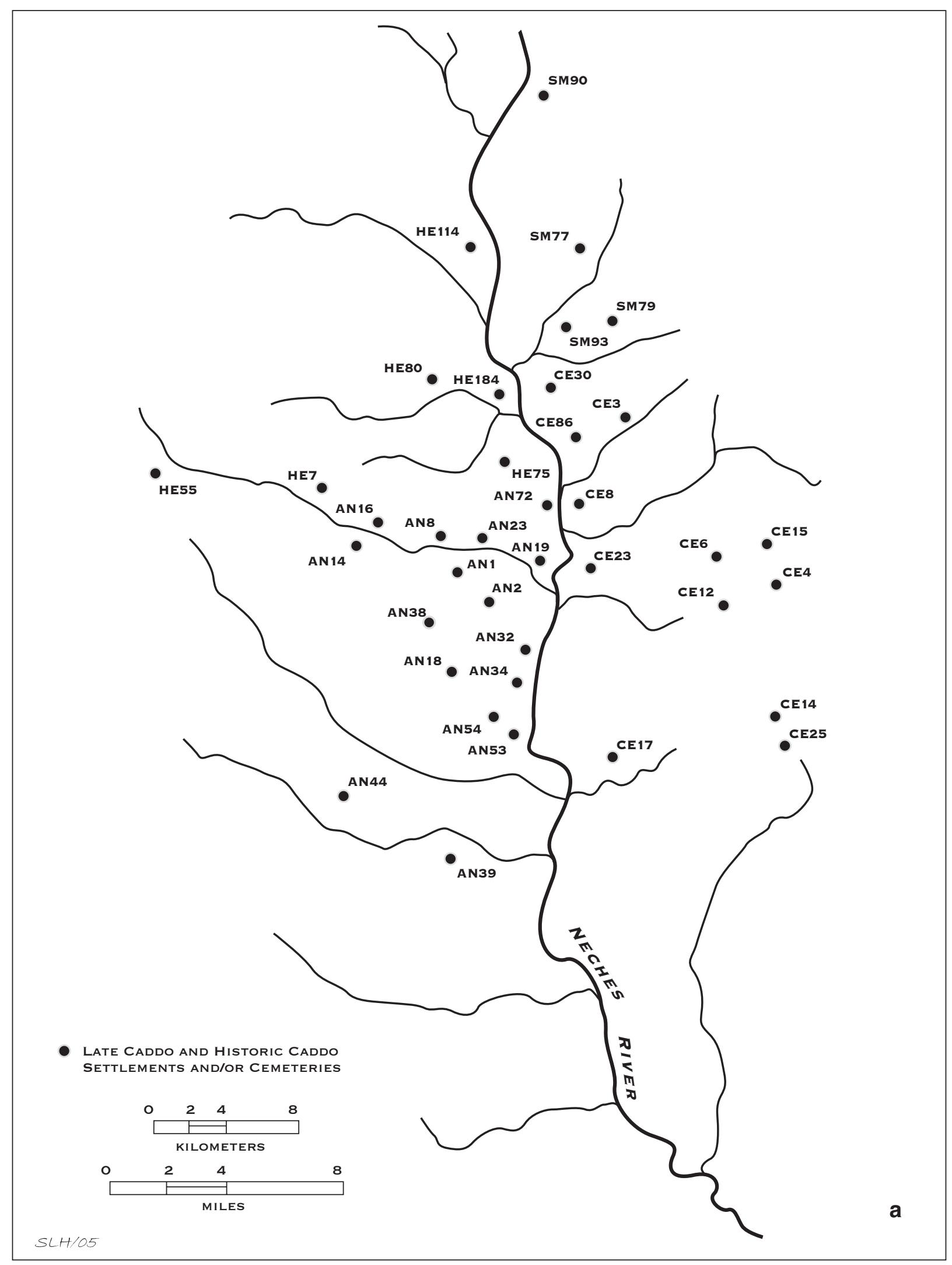

Figure 2. Distribution of Hood Engraved effigy vessels in the upper Neches River basin: a, sites in the Neches and Angelina River basin. 


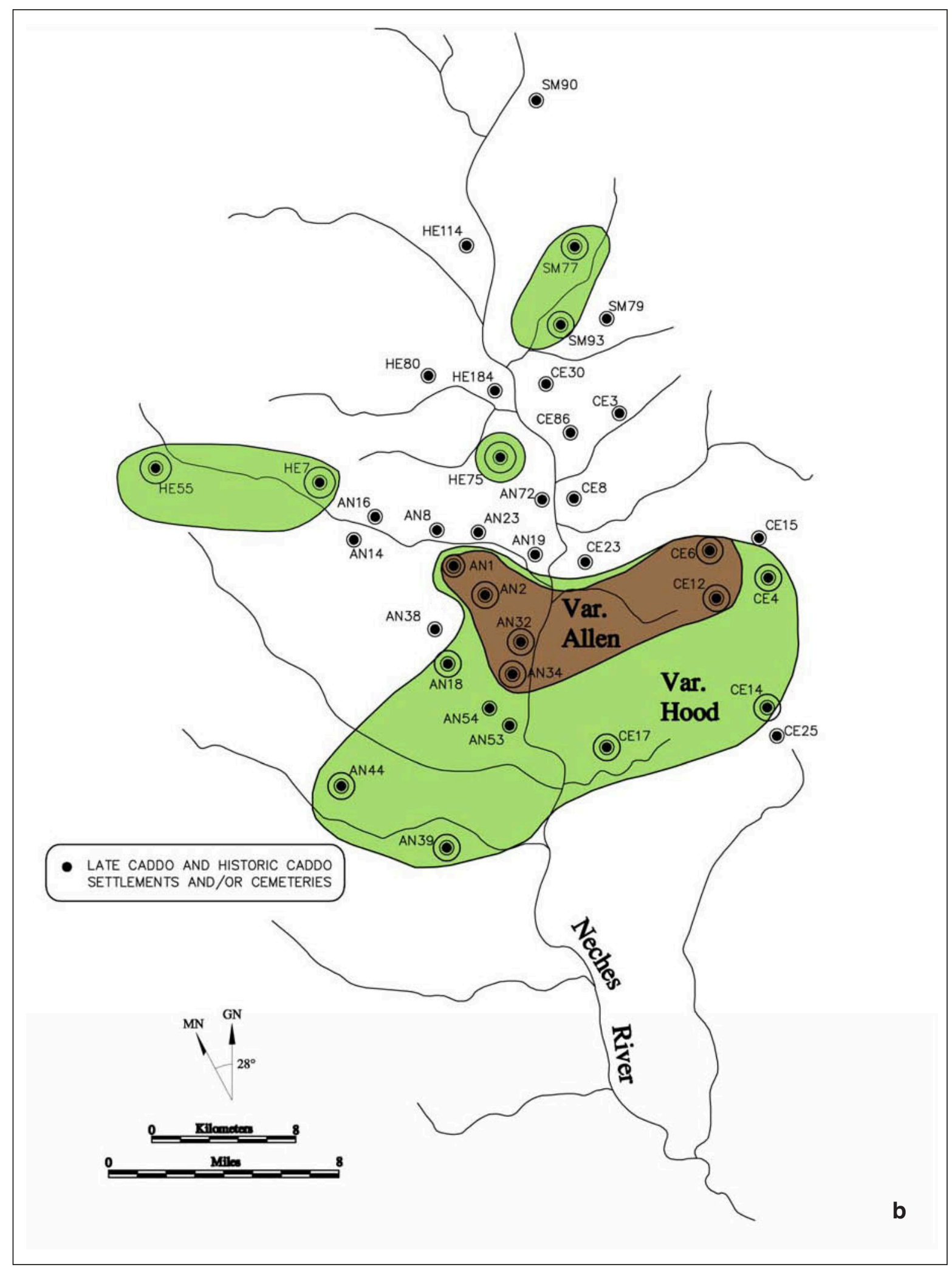

Figure 2. Distribution of Hood Engraved effigy vessels in the upper Neches River basin: b, sites with Hood Engraved effigy vessels. 
HEIGHT: $10.5 \mathrm{~cm}$

ORIFICE DIAMETER: $18.5 \mathrm{~cm}$

DIAMETER AT BOTTOM OF RIM OR NECK: N/A

BASE DIAMETER: $4.0 \mathrm{~cm}$

ESTIMATED VOLUME: 0.8 liters

DECORATION: There are three widely-spaced horizontal engraved lines on the upper part of the vessel (Figure 3).

TYPE: Hood Engraved, var. Allen effigy vessel, previously referred to as an example of a Fulton Aspect effigy bowl (cf. Suhm and Jelks 1962:Plate 24f)
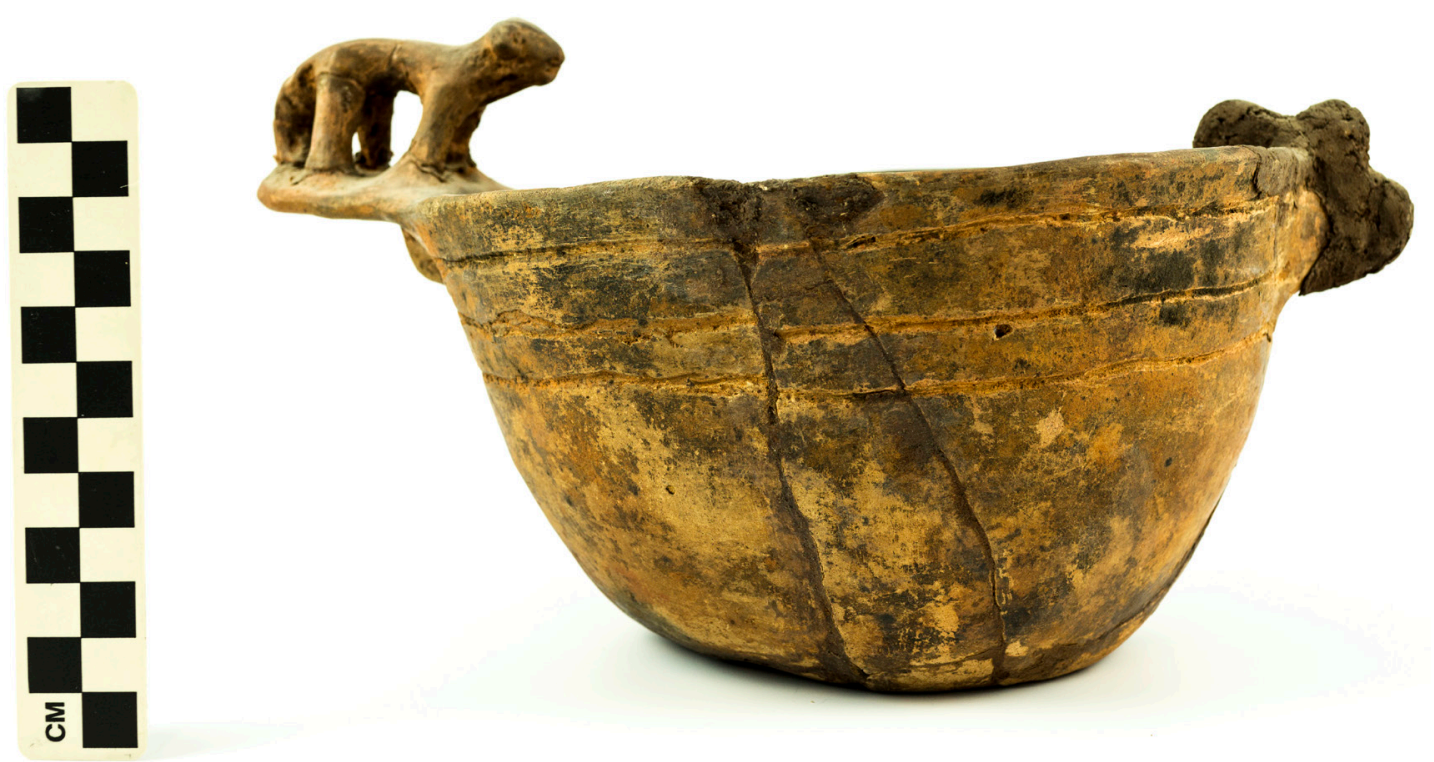

Figure 3. Hood Engraved, var. Allen effigy vessel from the Mrs. J. M. Cook site (41AN1). 
SITE NO.: 41AN1

FEATURE: Burial E-4

VESSEL NO.: 41AN1-23

NON-PLASTICS: grog and small amounts of hematite

VESSEL FORM: Effigy bowl with an everted rim and a rounded lip; the effigy head is missing, but there is a $3.4 \mathrm{~cm}$ wide tab tail on one end of the vessel (Figure 4)

CORE COLOR: A (fired and cooled in an oxidizing environment); pinkware

WALL THICKNESS: $5.6 \mathrm{~mm}$

INTERIOR SURFACE TREATMENT: burnished

EXTERIOR SURFACE TREATMENT: burnished

HEIGHT: $7.5 \mathrm{~cm}$

ORIFICE DIAMETER: $14.5 \mathrm{~cm}$

DIAMETER AT BOTTOM OF RIM OR NECK: N/A

BASE DIAMETER: $7.0 \mathrm{~cm}$

ESTIMATED VOLUME: 0.4 liters

DECORATION: There is an engraved panel on the rim with upper and lower sets of horizontally hatched pendant triangles (Figure 4). Each set has 12 triangles, with the apex of the upper set pointing downward, and the apex of the lower set pointing upwards. The apex of the two sets of triangles do not touch.

TYPE: Hood Engraved, var. Cook effigy bowl
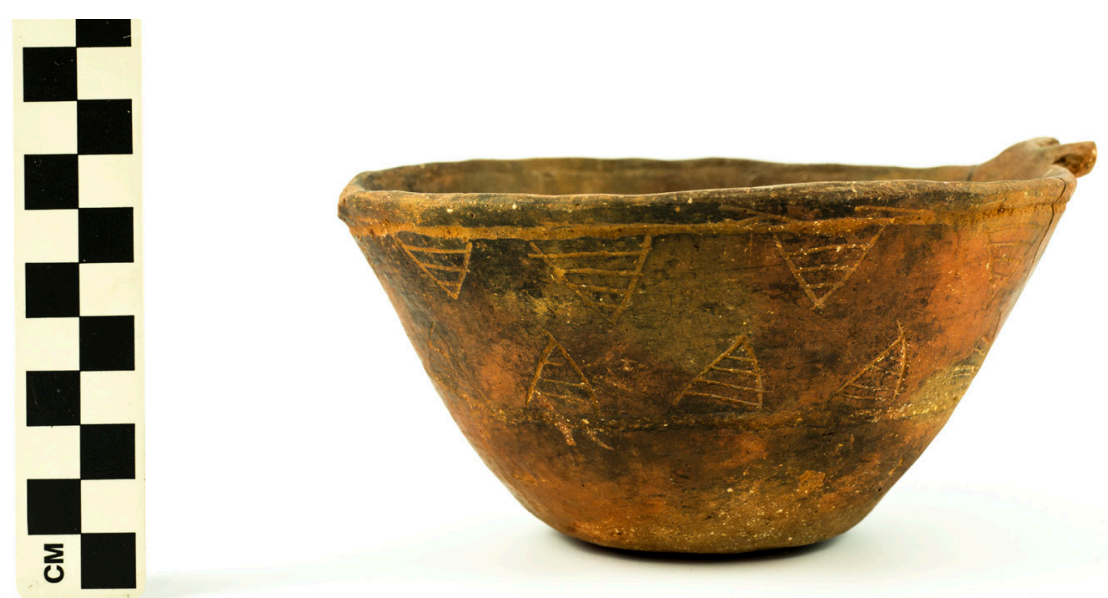

Figure 4. Hood Engraved, var. Cook effigy bowl from the Mrs. J. M. Cook site (41AN1). 
SITE NO.: 41AN1

FEATURE: Burial E-6

VESSEL NO.: 41AN1-34

NON-PLASTICS: grog and hematite

VESSEL FORM: Effigy bowl with a direct rim and a rounded lip. The effigy (a bird head) is attached to the rim at one end of the vessel and there is a tab tail at the opposite end of the vessel (Figure 5).

CORE COLOR: Undetermined

WALL THICKNESS: $6.3 \mathrm{~mm}$

INTERIOR SURFACE TREATMENT: smoothed

EXTERIOR SURFACE TREATMENT: smoothed

HEIGHT: $6.3 \mathrm{~cm}$

ORIFICE DIAMETER: $13.0 \mathrm{~cm}$

DIAMETER AT BOTTOM OF RIM OR NECK: N/A

BASE DIAMETER: $7.0 \mathrm{~cm}$

ESTIMATED VOLUME: 0.3 liters

DECORATION: Three broad and widely-spaced horizontal engraved lines on the rim (Figure 5); a red clay pigment has been rubbed in the engraved lines.

TYPE: Hood Engraved, var. Hood effigy vessel
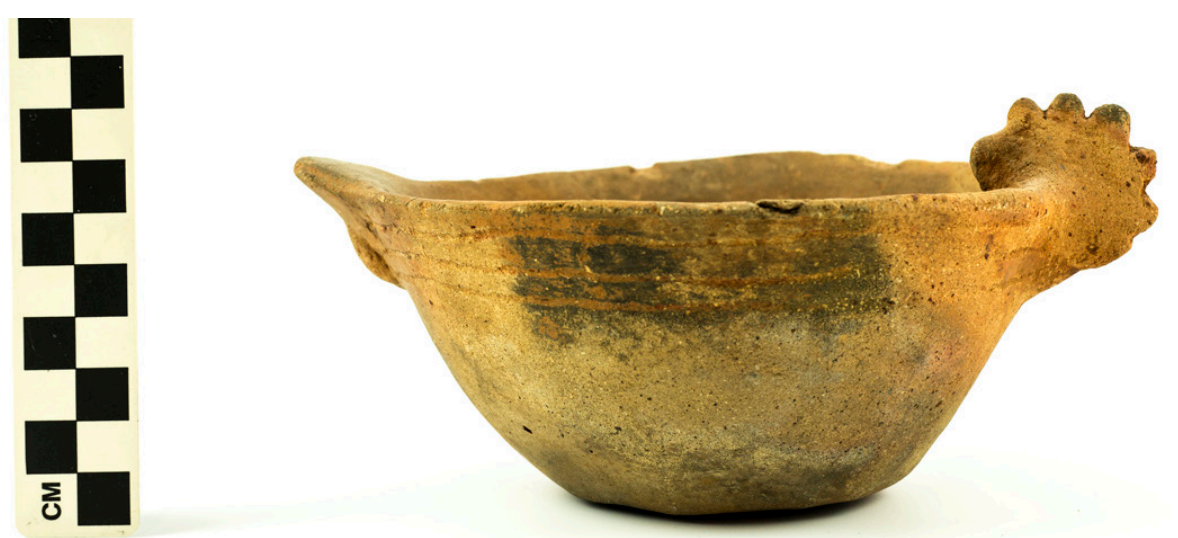

Figure 5. Hood Engraved, var. Hood effigy vessel from the Mrs. J. M. Cook site (41AN1). 


\section{Pierce Freeman Site (41AN34)}

The Pierce Freeman site is a small probable Allen phase Caddo cemetery excavated by UT archaeologists in 1931; the landowner had first found the site in 1914 (Cole 1975:89). Twenty ceramic vessels were among the funerary objects from the four excavated burials; there were no European trade goods recovered from the site (Marceaux 2011:424).

SITE NAME OR SITE NUMBER: Pierce Freeman

VESSEL NO.: 41AN34-17; Burial D-2

NON-PLASTICS AND PASTE: grog and hematite; fine sandy paste

VESSEL FORM: Effigy bowl with opposed effigy head and tail rider

RIM AND LIP FORM: Direct rim and flat lip

CORE COLOR: B (fired and cooled in a reducing environment)

INTERIOR SURFACE COLOR: very dark gray

EXTERIOR SURFACE COLOR: very dark gray

WALL THICKNESS (RIM, BODY, AND BASE

IN MM): rim, $8.0 \mathrm{~mm}$
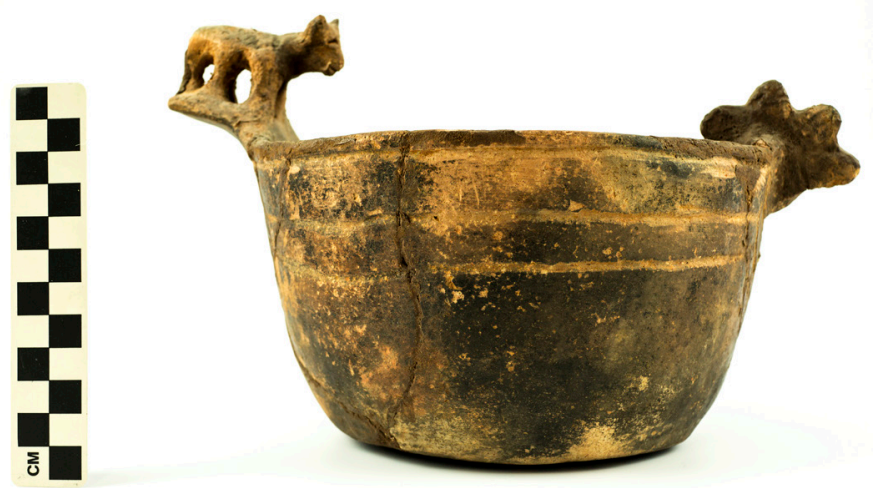

INTERIOR SURFACE TREATMENT: none

Figure 6. Hood Engraved, var. Allen effigy vessel from the Pierce Freeman site (41AN34).

EXTERIOR SURFACE TREATMENT: smoothed on the rim and body

HEIGHT (IN CM): $10.5 ; 16.3 \mathrm{~cm}$ at top of the tail rider

ORIFICE DIAMETER (IN CM): 17.6

DIAMETER AT BOTTOM OF RIM OR NECK (IN CM): N/A

BASE DIAMETER (IN CM) AND SHAPE OF BASE: 12.3; circular and flat

ESTIMATED VOLUME (IN LITERS): 0.74

DECORATION (INCLUDING MOTIF AND ELEMENTS WHEN APPARENT): The rim of the bowl has three horizontal engraved lines (Figure 6). The horizontal engraved lines dip under the opposed attachments. The effigy head appears to be a bird facing outwards, while the tail rider is looking inward towards the effigy head (Figure 6). the tail rider is a quadruped, possibly a dog or bear, with a long tail, and a head with two eyes, mouth, and erect ears.

PIGMENT USE AND LOCATION ON VESSEL: none

TYPE AND VARIETY [IF KNOWN]: Hood Engraved, var. Allen 


\section{Jasper Tucker/Mrs. Joe Watkins Farm Site (41AN44)}

The Jasper Tucker/Mrs. Joe Watkins Farm site is a Late Caddo period Frankston phase habitation site and small cemetery in the upper Neches River basin in East Texas. There are three known burials from the site, one dug by local farmers and the other two excavated by UT archaeologists in November 1935 (Woolsey 1935c). The two burials excavated by UT had 11 ceramic vessels (including Poynor Engraved and Maydelle Incised vessels), an L-shaped elbow pipe, and five Perdiz arrow points as funerary offerings. One burial (AO-1) had five effigy bowls, and burial AO-2 had one effigy bow. The proportion of effigy bowls among the vessels ( 55 percent) in the two burials is particularly notable.

SITE NO.: 41AN44

FEATURE: Burial AO-1

VESSEL NO:: AN44-3

NON-PLASTICS: grog

VESSEL FORM: Bowl

RIM AND LIP FORM: direct rim and rounded lip

CORE COLOR: $\mathrm{F}$ (fired in a reducing environment but cooled in the open air)

INTERIOR SURFACE COLOR: reddish-brown
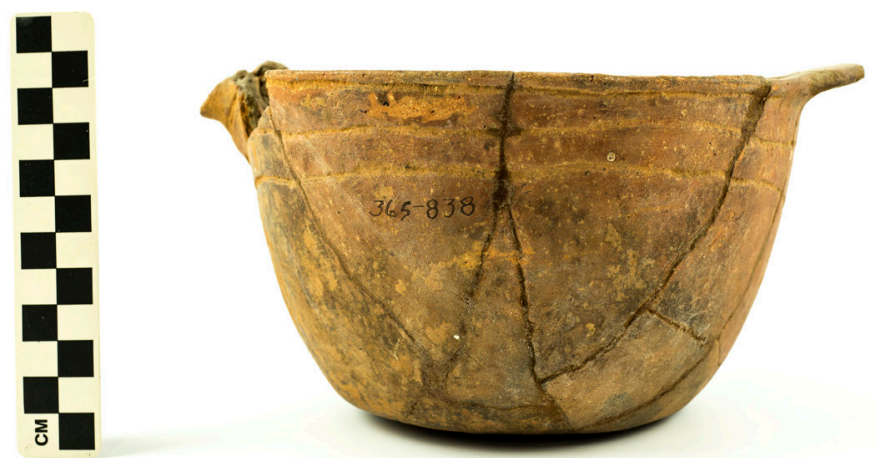

Figure 7. Hood Engraved, var. Hood effigy bowl (AN44-3) from the Jasper Tucker/Mrs. Joe Watkins Farm Site (41AN44).

EXTERIOR SURFACE COLOR: reddish-brown; fire clouds on the body and base

WALL THICKNESS: rim, $6.2 \mathrm{~mm}$

INTERIOR SURFACE TREATMENT: smoothed

EXTERIOR SURFACE TREATMENT: smoothed

HEIGHT: 10.5

ORIFICE DIAMETER: 16.9

DIAMETER AT BOTTOM OF RIM OR NECK: N/A

BASE DIAMETER AND SHAPE: 11.2; circular and flat

ESTIMATED VOLUME: 0.71 liters

DECORATION: three horizontal engraved lines around the rim; the engraved lines dip under the effigy head and tab tail. The effigy head on this vessel has been broken off (Figure 7). The tab tail is $55 \times 21 \times 8$ $\mathrm{mm}$ in width, length, and thickness.

PIGMENT: none

TYPE: Hood Engraved, var. Hood 
SITE NO.: 41AN44

FEATURE: Burial AO-1

VESSEL NO.: AN44-4

NON-PLASTICS: grog and hematite

VESSEL FORM: Bowl

RIM AND LIP FORM: direct rim and rounded lip

CORE COLOR: A (fired and cooled in an oxidizing environment)

INTERIOR SURFACE COLOR: light brown; fire clouds on the rim

EXTERIOR SURFACE COLOR: brown; fire clouds on the rim and body

WALL THICKNESS: rim, $5.7 \mathrm{~mm}$

INTERIOR SURFACE TREATMENT: smoothed EXTERIOR SURFACE TREATMENT: smoothed

HEIGHT: 8.0

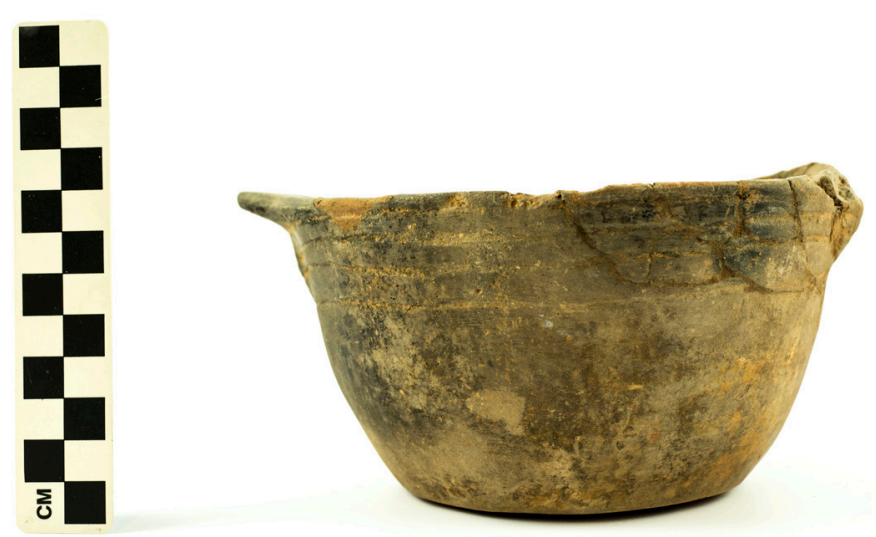

Figure 8. Hood Engraved, var. Hood effigy bowl (AN44-4) from the Jasper Tucker/Mrs. Joe Watkins Farm Site (41AN44).

ORIFICE DIAMETER: 15.1

DIAMETER AT BOTTOM OF RIM OR NECK: N/A

BASE DIAMETER AND SHAPE: 9.5; circular and flat

ESTIMATED VOLUME: 0.48 liters

DECORATION: four horizontal lines on the vessel rim; the engraved lines do not dip under the effigy head or tab tail. The effigy head is broken off, but the tab tail is $42 \times 24$ × $8 \mathrm{~mm}$ in length, width, and thickness (Figure 8).

PIGMENT: none

TYPE: Hood Engraved, var. Hood 
SITE NO.: 41AN44

FEATURE: Burial AO-1

VESSEL NO.: 41AN44-6

NON-PLASTICS: grog

VESSEL FORM: Bowl

RIM AND LIP FORM: direct rim and rounded lip

CORE COLOR: A (fired and cooled in an oxidizing environment)

INTERIOR SURFACE COLOR: light brown

EXTERIOR SURFACE COLOR: brown; fire clouds on the rim, body, and base

WALL THICKNESS: rim, $5.6 \mathrm{~mm}$

INTERIOR SURFACE TREATMENT: smoothed

EXTERIOR SURFACE TREATMENT: smoothed

HEIGHT: $10.5 ; 15.4 \mathrm{~cm}$ at the top of the effigy head

ORIFICE DIAMETER: 17.8

DIAMETER AT BOTTOM OF RIM OR NECK: N/A
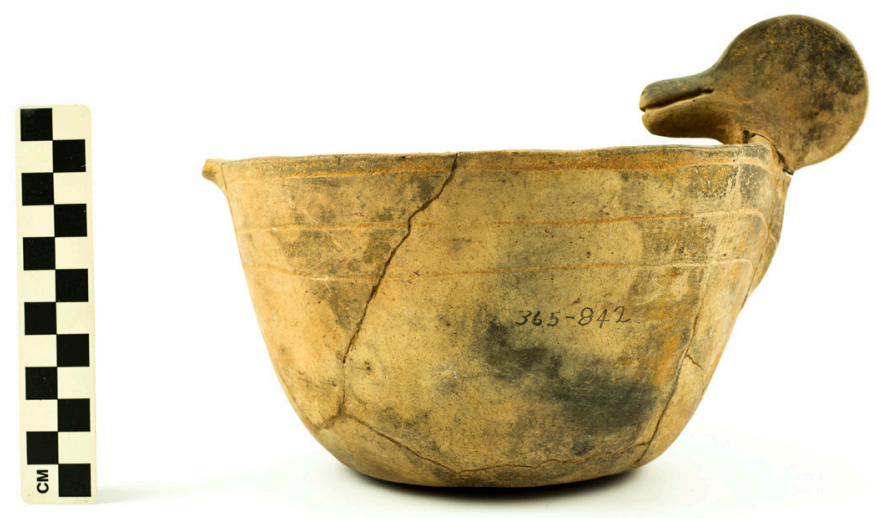

BASE DIAMETER AND SHAPE: 11.2; circular and flat

Figure 9. Hood Engraved, var. Hood effigy bowl (AN44-6) from the Jasper Tucker/Mrs. Joe Watkins Farm Site (41AN44).

ESTIMATED VOLUME: 0.75 liters

DECORATION: There are three horizontal engraved lines on the upper part of the bowl (Figure 9). These lines dip down underneath the effigy head and the tab tail.

The effigy head (51 x 73 x 11-18 mm in height, width, and thickness) resembles a duck head. It is facing inwards towards the tab tail, which is broken off. The effigy head has an engraved slit for its mouth and two circular holes for the nose; there are no eyes (see Figure 9). The tab tail is $66 \mathrm{~mm}$ in width.

PIGMENT: none

TYPE: Hood Engraved, var. Hood 
SITE NO.: 41AN44

FEATURE: Burial AO-1

VESSEL NO.: AN44-7

NON-PLASTICS: grog and hematite

VESSEL FORM: Bowl

RIM AND LIP FORM: direct rim and rounded lip

CORE COLOR: A (fired and cooled in an oxidizing environment)

INTERIOR SURFACE COLOR: light reddish-brown

EXTERIOR SURFACE COLOR: light reddish-brown

WALL THICKNESS: rim, $5.0 \mathrm{~mm}$

INTERIOR SURFACE TREATMENT: none

EXTERIOR SURFACE TREATMENT: smoothed

HEIGHT: $8.5 ; 12.0 \mathrm{~cm}$ atop the effigy head

ORIFICE DIAMETER: 14.6

DIAMETER AT BOTTOM OF RIM OR NECK:

N/A

BASE DIAMETER AND SHAPE: 10.4; circular and flat

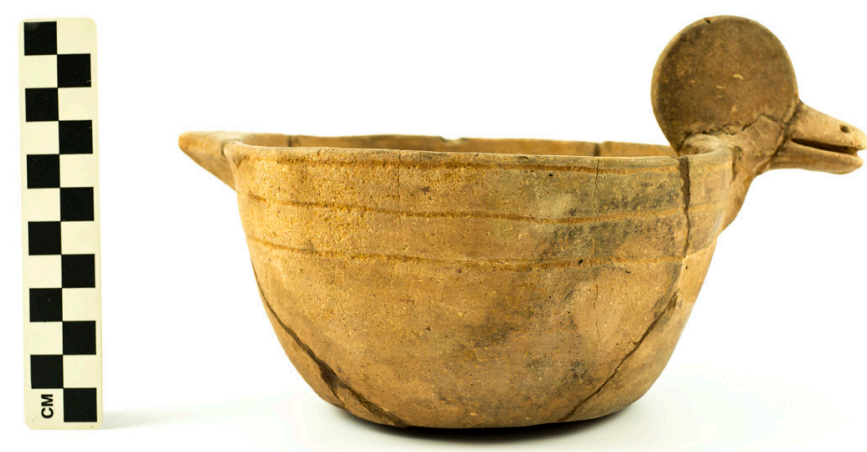

Figure 10. Hood Engraved, var. Hood effigy bowl (AN44-7) from the Jasper Tucker/Mrs. Joe Watkins Farm Site (41AN44).

ESTIMATED VOLUME: 0.5 liters

DECORATION: There are three horizontal engraved lines around the rim (Figure 10). These lines dip below the effigy head and tab tail. There is a single horizontal engraved line across the tab tail.

The effigy head appears to be a duck head; it faces outward. It has an engraved slit for its mouth and two circular holes for its nose; there are no eyes (see Figure 10). It measures 51 x 73 x $11 \mathrm{~mm}$ in height, width, and thickness. The tab tail is 57 x 27 x $14 \mathrm{~mm}$ in length, width, and thickness.

PIGMENT: none

TYPE: Hood Engraved, var. Hood 
SITE NO.: 41AN44

FEATURE: Burial AO-1

VESSEL NO.: AN44-8

NON-PLASTICS: grog

VESSEL FORM: Bowl

RIM AND LIP FORM: direct rim and a flat lip

CORE COLOR: A (fired and cooled in an oxidizing environment)

INTERIOR SURFACE COLOR: light brown

EXTERIOR SURFACE COLOR: light brown to brown

WALL THICKNESS: rim, $5.4 \mathrm{~mm}$

INTERIOR SURFACE TREATMENT: smoothed

EXTERIOR SURFACE TREATMENT: smoothed to burnished

HEIGHT: $10.0 ; 14.6 \mathrm{~cm}$ in height atop effigy head

ORIFICE DIAMETER: 15.4

DIAMETER AT BOTTOM OF RIM OR NECK: N/A

BASE DIAMETER AND SHAPE: 10.2; circular and flat
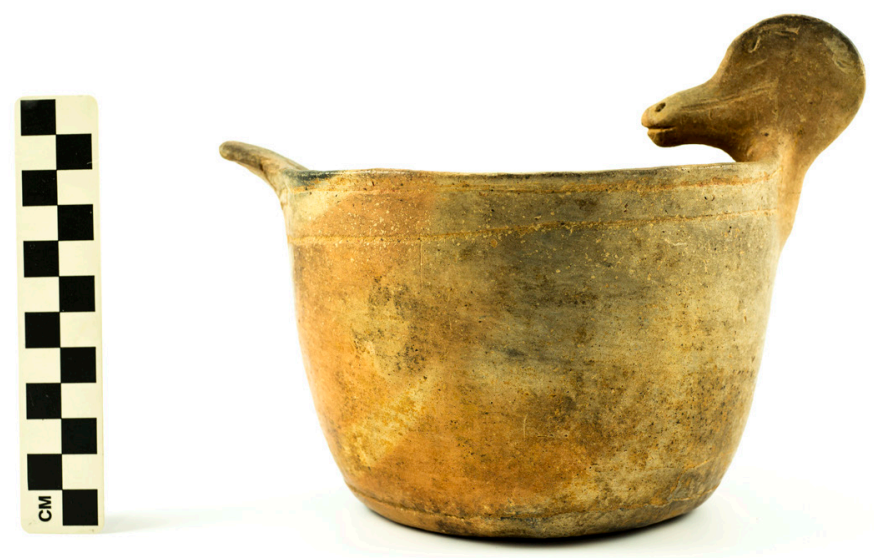

Figure 11. Hood Engraved, var. Hood effigy bowl (AN44-8) from the Jasper Tucker/Mrs. Joe Watkins

ESTIMATED VOLUME: 0.62 liters Farm Site (41AN44).

DECORATION: There are three horizontal engraved lines on the vessel, two below the rim and a third above the vessel base (Figure 11). The upper two engraved lines are continuous under the tab tail, but terminate at and below the effigy head attachment.

The effigy head resembles a duck head; it is facing inwards towards the tab tail. The duck head has an engraved slit for its mouth and two circular holes for its nose; there are no eyes (see Figure 11). The effigy head is $41 \times 62 \times 9 \mathrm{~mm}$ in height, width, and thickness. The tab tail is $39 \times 24 \times 9 \mathrm{~mm}$ in length, width, and thickness.

PIGMENT: none

TYPE: Hood Engraved, var. Hood 
SITE NO.: 41AN44

FEATURE: Burial AO-2

VESSEL NO.: AN44-14

NON-PLASTICS: grog

VESSEL FORM: Bowl

RIM AND LIP FORM: direct rim and rounded lip

CORE COLOR: A (fired and cooled in an oxidizing environment)

INTERIOR SURFACE COLOR: reddish-brown; fire clouds on the base

EXTERIOR SURFACE COLOR: reddish-brown; fire clouds on the rim and body

WALL THICKNESS: rim, $4.6 \mathrm{~mm}$

INTERIOR SURFACE TREATMENT: none

EXTERIOR SURFACE TREATMENT: none

HEIGHT: $3.5 ; 5.3 \mathrm{~cm}$ atop the effigy head

ORIFICE DIAMETER: 8.8

DIAMETER AT BOTTOM OF RIM OR NECK: N/A

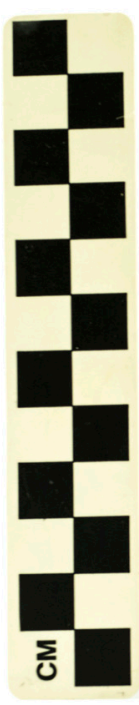

BASE DIAMETER AND SHAPE: 2.9; circular and flat

Figure 12. Hood Engraved, var. Hood effigy bowl (AN44-14) from the Jasper Tucker/Mrs. Joe Watkins Farm Site (41AN44).

ESTIMATED VOLUME: 0.13 liters

DECORATION: There are two to three irregularly executed horizontal engraved lines below the rim (Figure 12). These lines do not dip below the effigy head and tab tail attachments.

The effigy head ( $22 \times 14 \times 10 \mathrm{~mm}$ in height, width, and thickness) appears to be the head, mouth, and ears of an unknown animal; it is not a bird head. The head faces inwards towards the tab tail (see Figure 12). The tab tail is partly broken off the vessel; it is $21 \mathrm{~mm}$ in width and $6.0 \mathrm{~mm}$ in thickness.

PIGMENT: red pigment in engraved lines

TYPE: Hood Engraved, var. Hood 


\section{The O. L. Ellis Site (41AN54)}

The O. L. Ellis site (41AN54) may be an early Allen phase habitation site and small cemetery on Boggy Creek in the upper Neches River basin. The cemetery was discovered by local farmers in 1934 or 1935, and they excavated two burials. UT archaeologists excavated two more burials (AE-1 and AE-2) in September 1935 (Jackson 1935).

Between the vessels purchased by UT from local farmers and those they recovered in two burials, a total of 14 ceramic vessels had been placed as funerary offerings with the four ancestral Caddo burials. The vessels include the one effigy vessel discussed below as well as a Hume Engraved bottle, two Patton Engraved vessels (with two rows of large pendant triangles like a Patton Engraved, var. Allen carinated bowl from the Vanderpool site [41SM77] in the upper Neches River basin, see Perttula et al. 2013:Figure 10), Poynor Engraved, var. Hood carinated bowls, a Maydelle Incised jar, and brushed-punctated (fingernail punctates on the rim and vertical brushing on the vessel body; one of these has an appliqued loop handle) and incised-appliqued jars.

SITE NO.: 41AN54

FEATURE: Burial 1

VESSEL NO.: AN54-4

NON-PLASTICS: grog

VESSEL FORM: Bowl

RIM AND LIP FORM: direct rim and rounded lip

CORE COLOR: F (fired in a reducing environment and cooled in the open air)

INTERIOR SURFACE COLOR: reddish-brown; fire clouds on the body

EXTERIOR SURFACE COLOR: dark reddish-brown; fire clouds on the rim, body, and base

WALL THICKNESS: rim, $5.6 \mathrm{~mm}$

INTERIOR SURFACE TREATMENT: smoothed

EXTERIOR SURFACE TREATMENT: smoothed

HEIGHT: $9.0 ; 12.5 \mathrm{~cm}$ in height atop the effigy head

ORIFICE DIAMETER: 16.5

DIAMETER AT BOTTOM OF RIM OR NECK: N/A

BASE DIAMETER AND SHAPE: 9.3; circular and flat

ESTIMATED VOLUME: 0.59 liters 
DECORATION: There are three horizontal engraved lines below the rim (Figure 13). The lines do not dip below the effigy head or tail rider attachments.

The effigy head is a bird's head with four prongs (one partially broken) or notching along its perimeter. The head also had two excised circles for eyes. The tail rider attachment is a quadruped with a long tail. Its head, with two ears, is facing inwards towards the effigy head (see Figure 13). The tail rider is 73 x $42 \times 37 \mathrm{~mm}$ in length, width, and height.

PIGMENT: white pigment in engraved lines

TYPE: Hood Engraved, var. Allen

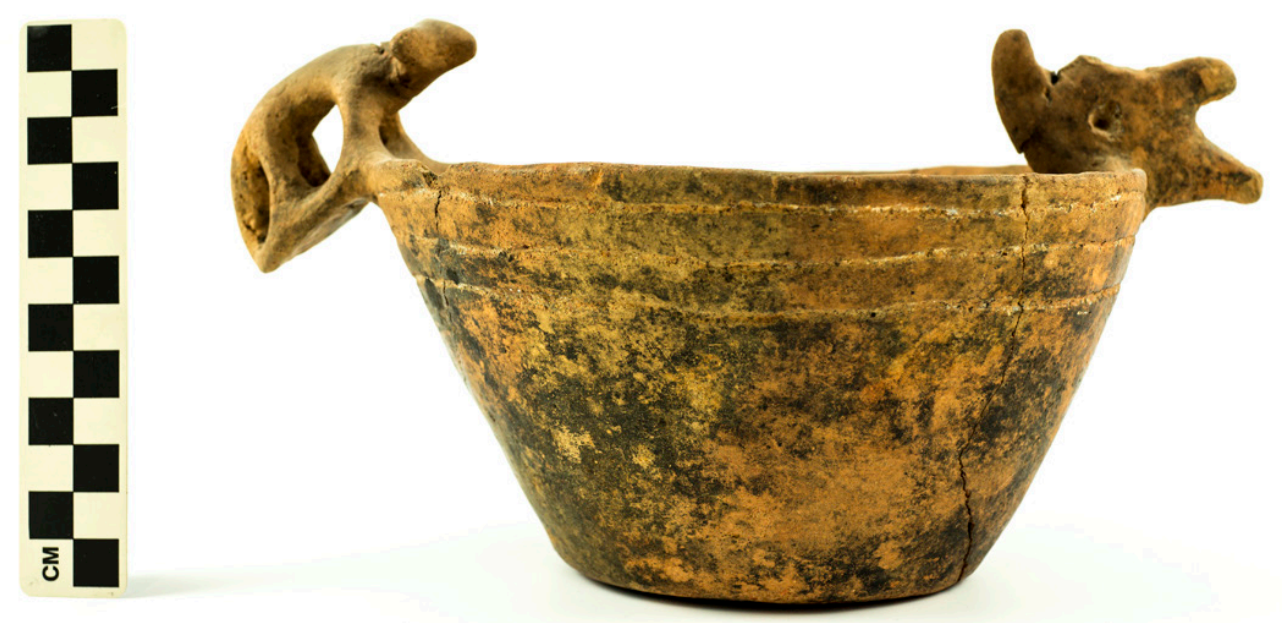

Figure 13. Hood Engraved, var. Allen effigy bowl from the O. L. Ellis site (41AN54).

\section{Mrs. J. W. Blackburn Site (41CE4)}

The J. W. Blackburn site had six burials in a small cemetery (Woolsey 1935d). The 24 vessels recovered from the burials include 13 carinated bowls, seven bottles, one bowl, and three jars. Kleinschmidt (1982) considers the cemetery to have been used during sub-phase 2 of the Frankston phase, dating from ca. A.D. 1480-1560 (Perttula et al. 2011).

In addition to the one Hood Engraved effigy bowl in the vessels, there are Poynor Engraved carinated bowls of vars. Blackburn, Cook, and Hood, as well as local varieties var. C and var. D, and Hume Engraved bottles. There are also three Killough Pinched jars, two with distinctive pedestal bases.

SITE NO.: 41CE4

FEATURE: Burial AI-4

VESSEL NO.: 41CE4-50

NON-PLASTICS: grog 
VESSEL FORM: Bowl with a direct rim and a rounded lip; bird head effigy at one end of the vessel, and the associated tab tail at the other end has been broken away (Figure 14)

CORE COLOR: F (fired in a reducing environment, but cooled in the open air); pinkware

WALL THICKNESS: $6.9 \mathrm{~mm}$

INTERIOR SURFACE TREATMENT: smoothed on the rim

EXTERIOR SURFACE TREATMENT: smoothed

HEIGHT: $10.2 \mathrm{~cm}$

ORIFICE DIAMETER: $20.5 \mathrm{~cm}$

DIAMETER AT BOTTOM OF RIM OR NECK: N/A

BASE DIAMETER: $12.0 \mathrm{~cm}$

ESTIMATED VOLUME: 0.8 liters

DECORATION: Four widely spaced horizontal engraved lines on the upper part of the vessel (Figure 14). The effigy head is facing inwards towards the other side of the vessel and the tab tail. House (2003:54) suggests this is a stylized "ventral (belly-upward)" portrayal of the bird.

TYPE: Hood Engraved, var. Hood effigy vessel
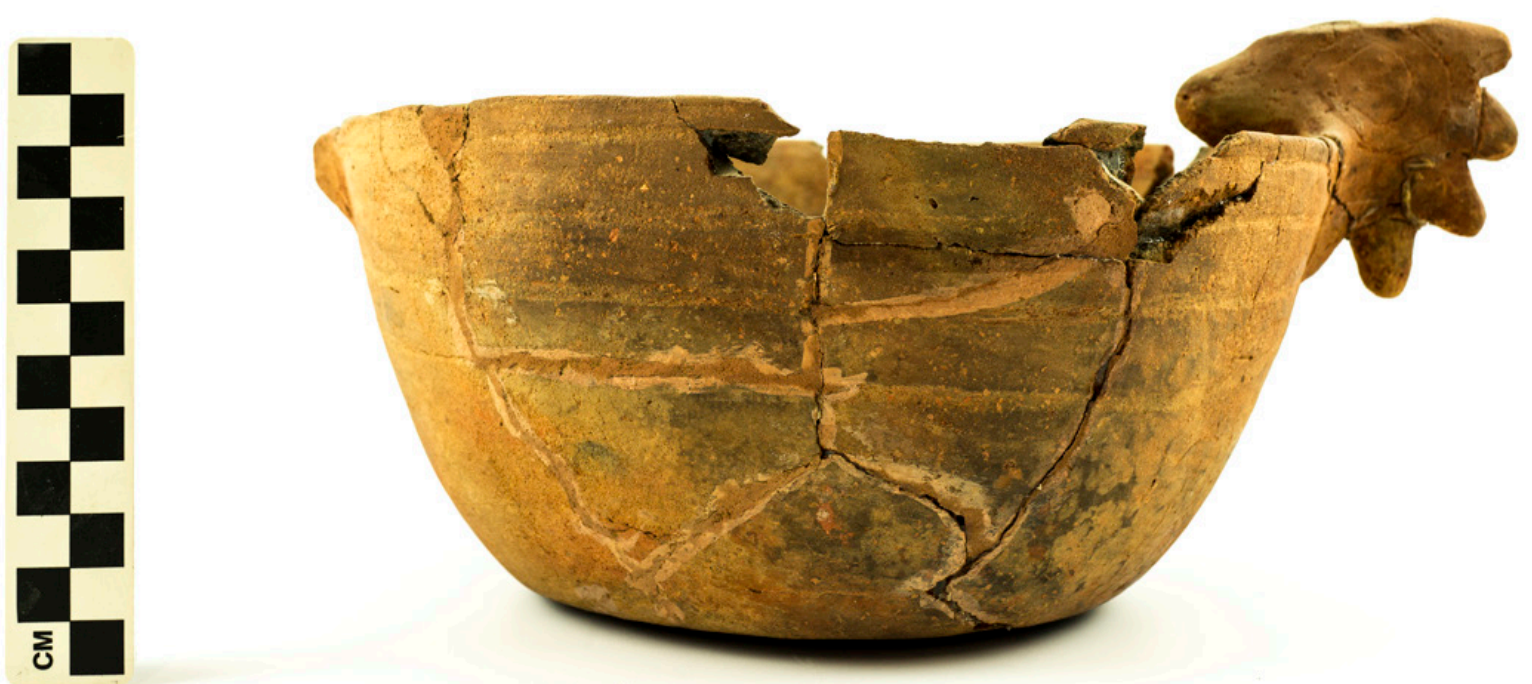

Figure 14. Hood Engraved, var. Hood effigy vessel from the Mrs. J. W. Blackburn site (41CE4). 


\section{E. W. Hackney Site (41CE6)}

The E. W. Hackney site is an ancestral Caddo habitation site and small cemetery on a tributary of Killough Creek in the upper Neches River basin. UT archaeologists excavated two burials at the site in 1935 (Cole 1975:101-110; Marceaux 2011:424; Woolsey 1935a) and also identified a nearby midden area. In addition to the recovery of eight ceramic vessels, a possible gunflint and a brass hawk bell were among the funerary objects in the burials.

SITE NAME OR SITE NUMBER: E. W. Hackney

VESSEL NO.: 41CE6-7; Burial AN-2

NON-PLASTICS AND PASTE: grog and hematite; fine sandy paste

VESSEL FORM: Effigy bowl with opposed effigy head and tail rider

RIM AND LIP FORM: Direct rim and rounded lip

CORE COLOR: $\mathrm{F}$ (fired in a reducing

environment and cooled in the open air)

INTERIOR SURFACE COLOR: brown; fire clouds on the rim and body

EXTERIOR SURFACE COLOR: brown; fire clouds on the base

WALL THICKNESS (RIM, BODY, AND BASE IN MM): rim, $7.5 \mathrm{~mm}$

INTERIOR SURFACE TREATMENT: smoothed on the upper part of the vessel

EXTERIOR SURFACE TREATMENT: smoothed on the upper part of the vessel

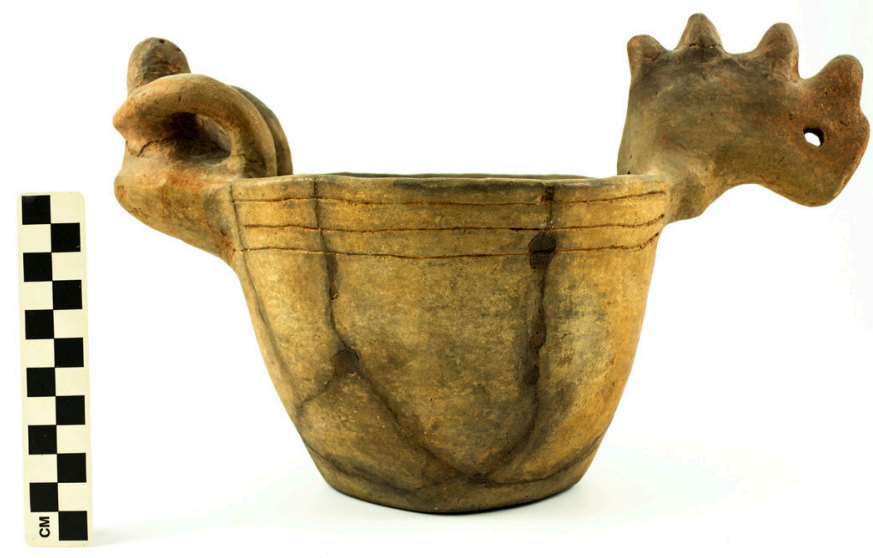

Figure 15. Hood Engraved, var. Allen effigy bowl from the E. W. Hackney site (41CE6).

HEIGHT (IN CM): $12.8 ; 18.6 \mathrm{~cm}$ atop the tail rider's head

ORIFICE DIAMETER (IN CM): 17.5

DIAMETER AT BOTTOM OF RIM OR NECK (IN CM): N/A

BASE DIAMETER (IN CM) AND SHAPE OF BASE: 10.0, circular and flat

ESTIMATED VOLUME (IN LITERS): 0.9

DECORATION (INCLUDING MOTIF AND ELEMENTS WHEN APPARENT): There are three discontinuous horizontal engraved lines on the vessel rim; the lines are discontinuous beneath the effigy head and the tail rider (Figure 15). The effigy head is that of a bird or duck with a crested head, and the tail rider is an anthropomorphic figure with a head, trunk, and arms/hands; the arms/hands are attached to the vessel rim.

PIGMENT USE AND LOCATION ON VESSEL: red pigment in engraved lines

TYPE AND VARIETY [IF KNOWN]: Hood Engraved, var. Allen 


\section{Jim P. Allen Site (41CE12)}

The Jim P. Allen site is also situated about $0.8 \mathrm{~km}$ from Killough Creek in the upper Neches River basin. UT archaeologists excavated 18 burials at the site in 1935 (Woolsey 1935b), after the landowner had found and excavated one burial (Perttula et al. 2011:Figure 11-7), and there were three nearby midden areas associated with the cemetery (Cole 1975:35 and Figure 2). One of the 19 burials had European glass trade beads and a brass tinkler (Marceaux 2011:425-426).

SITE NAME OR SITE NUMBER: Jim P. Allen

VESSEL NO.: 41CE12-8; Burial AH-2

NON-PLASTICS AND PASTE: grog and hematite

VESSEL FORM: Effigy bowl with attached opposed effigy heads

RIM AND LIP FORM: Direct rim and rounded lip

CORE COLOR: A (fired and cooled in an oxidizing environment)

INTERIOR SURFACE COLOR: light brown; fire clouds on the body and base

EXTERIOR SURFACE COLOR: light brown; fire clouds on the base

WALL THICKNESS (RIM, BODY, AND BASE IN MM): rim, $6.4 \mathrm{~mm}$

INTERIOR SURFACE TREATMENT: smoothed on the rim and body

EXTERIOR SURFACE TREATMENT: smoothed on the rim and body

HEIGHT (IN CM): 7.0

ORIFICE DIAMETER (IN CM): 13.0

DIAMETER AT BOTTOM OF RIM OR NECK (IN CM): N/A

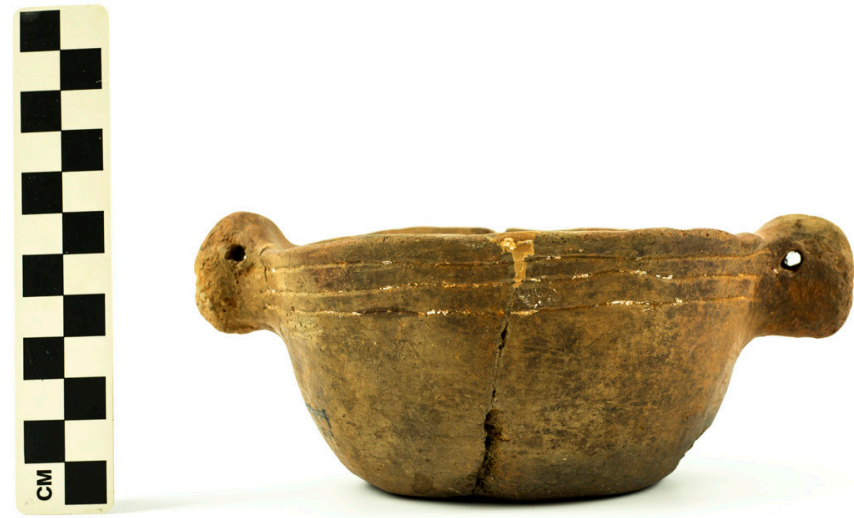

Figure 16. Hood Engraved, var. Hood effigy bowl (41CE12-8) from the Jim P. Allen site (41CE12).

BASE DIAMETER (IN CM) AND SHAPE OF BASE: 8.0; circular and flat

ESTIMATED VOLUME (IN LITERS): 0.4

DECORATION (INCLUDING MOTIF AND ELEMENTS WHEN APPARENT): The vessel rim has three discontinuous horizontal engraved lines (Figure 16). The animal effigy heads have suspension holes for eyes.

PIGMENT USE AND LOCATION ON VESSEL: white pigment in engraved lines

TYPE AND VARIETY [IF KNOWN]: Hood Engraved, var. Hood 
SITE NAME OR SITE NUMBER: Jim P. Allen

VESSEL NO.: 41CE12-169; Burial AH-13

NON-PLASTICS AND PASTE: grog and hematite

VESSEL FORM: Effigy bowl with opposed effigy head and tail rider (Figure 17)

RIM AND LIP FORM: Direct rim and rounded lip

CORE COLOR: A (fired and cooled in an oxidizing environment)

INTERIOR SURFACE COLOR: pinkish-gray

EXTERIOR SURFACE COLOR: light brown; fire clouds on the base

WALL THICKNESS (RIM, BODY, AND BASE IN MM): rim, $5.7 \mathrm{~mm}$

INTERIOR SURFACE TREATMENT: smoothed

EXTERIOR SURFACE TREATMENT: smoothed

HEIGHT (IN CM): 9.7; $13.6 \mathrm{~cm}$ atop the effigy head

ORIFICE DIAMETER (IN CM): 14.6

DIAMETER AT BOTTOM OF RIM OR NECK

(IN CM): N/A

BASE DIAMETER (IN CM) AND SHAPE OF

BASE: 7.7; circular and flat

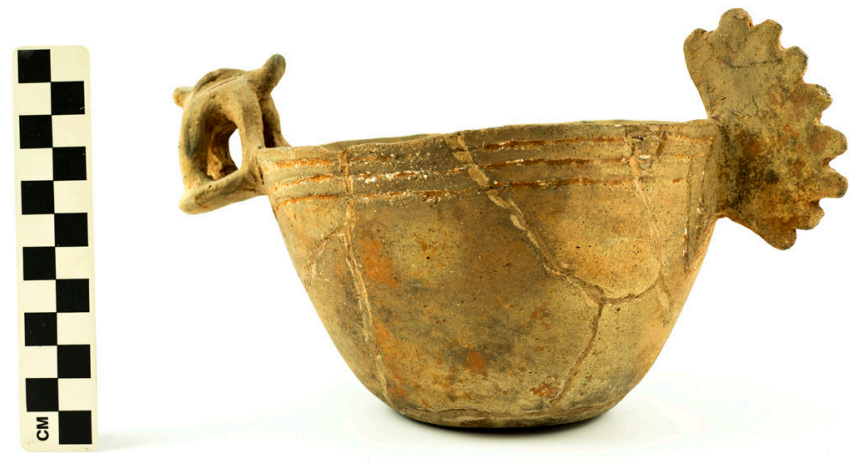

Figure 17. Hood Engraved, var. Allen effigy bowl (41CE12-169) from the Jim P. Allen site (41CE12).

\section{ESTIMATED VOLUME (IN LITERS): 0.6}

DECORATION (INCLUDING MOTIF AND ELEMENTS WHEN APPARENT): The rim has three horizontal engraved lines around the vessel; the horizontal engraved lines dip under the effigy head and tail rider (Figure 17). The effigy head resembles a coxcomb in profile, while the tail rider has its head facing inwards towards the back of the effigy head (Figure 17). The tail rider resembles a loggerhead turtle with its flat head, small tail, and three appliqued ridges on its back.

PIGMENT USE AND LOCATION ON VESSEL: white pigment in engraved lines

TYPE AND VARIETY [IF KNOWN]: Hood Engraved, var. Allen 
SITE NAME OR SITE NUMBER: Jim P. Allen

VESSEL NO.: 41CE12-176; Burial AH-14

NON-PLASTICS AND PASTE: grog and hematite

VESSEL FORM: Effigy bowl with opposed attachments (effigy head-missing — and a tail rider) (Figure 18)

RIM AND LIP FORM: Direct rim and rounded lip

CORE COLOR: A (fired and cooled in an oxidizing environment)

INTERIOR SURFACE COLOR: reddish-yellow

EXTERIOR SURFACE COLOR: reddish-yellow; fire clouds on the rim and body

WALL THICKNESS (RIM, BODY, AND BASE

IN MM): rim, $5.1 \mathrm{~mm}$

INTERIOR SURFACE TREATMENT: none

EXTERIOR SURFACE TREATMENT: none

HEIGHT (IN CM): $5.6 ; 7.6 \mathrm{~cm}$ in height atop the tail rider

ORIFICE DIAMETER (IN CM): 7.9

DIAMETER AT BOTTOM OF RIM OR NECK (IN CM): N/A

BASE DIAMETER (IN CM) AND SHAPE OF

BASE: 5.0; circular and flat

ESTIMATED VOLUME (IN LITERS): 0.2
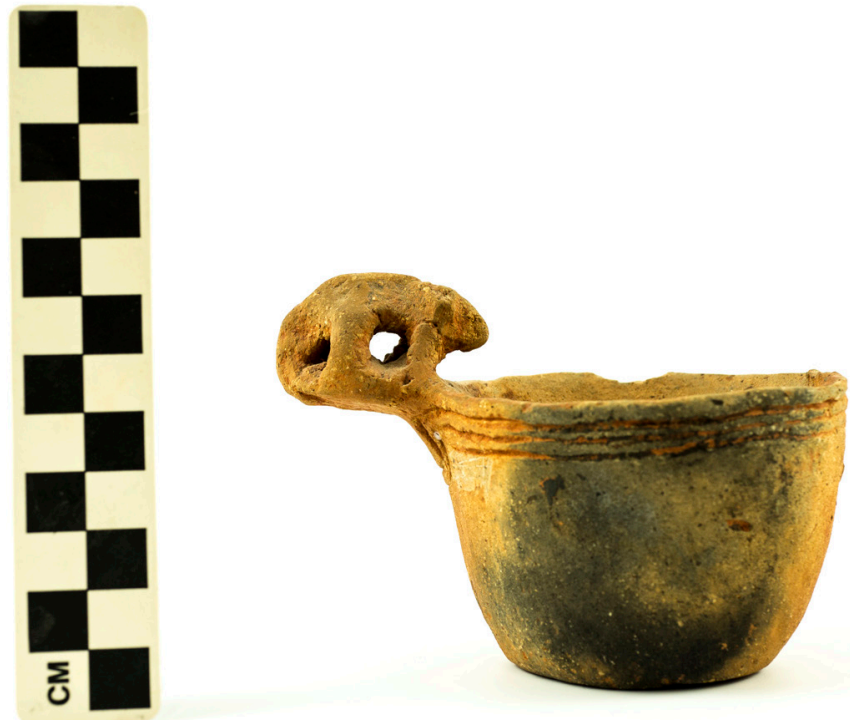

Figure 18. Hood Engraved, var. Allen effigy bowl (41CE12-176) from the Jim P. Allen site (41CE12).

DECORATION (INCLUDING MOTIF AND ELEMENTS WHEN APPARENT): The rim has three horizontal engraved lines that dip underneath the effigy head and tail rider attachments (Figure 18). The effigy head is missing, although its attachment area is apparent, and the tail rider is a quadruped facing inwards towards the effigy head. The tail rider has two ears, two small dots for eyes, and a tail.

PIGMENT USE AND LOCATION ON VESSEL: red clay pigment in engraved lines TYPE AND VARIETY [IF KNOWN]: Hood Engraved, var. Allen 
SITE NAME OR SITE NUMBER: Jim P. Allen

VESSEL NO.: 41CE12-181; Burial AH-16

NON-PLASTICS AND PASTE: grog and hematite

VESSEL FORM: Effigy bowl with opposed effigy head and tail rider

RIM AND LIP FORM: Direct rim and rounded lip

CORE COLOR: A (fired and cooled in an oxidizing environment); pinkware

INTERIOR SURFACE COLOR: brown

EXTERIOR SURFACE COLOR: yellowish-red; fire clouds on the rim and body

WALL THICKNESS (RIM, BODY, AND BASE IN MM): rim, 6.4 mm

INTERIOR SURFACE TREATMENT: smoothed

EXTERIOR SURFACE TREATMENT: smoothed

HEIGHT (IN CM): 10.6; $14.0 \mathrm{~cm}$ atop the effigy head

ORIFICE DIAMETER (IN CM): 16.6

DIAMETER AT BOTTOM OF RIM OR NECK (IN CM): N/A

BASE DIAMETER (IN CM) AND SHAPE OF BASE: 9.2; circular and flat

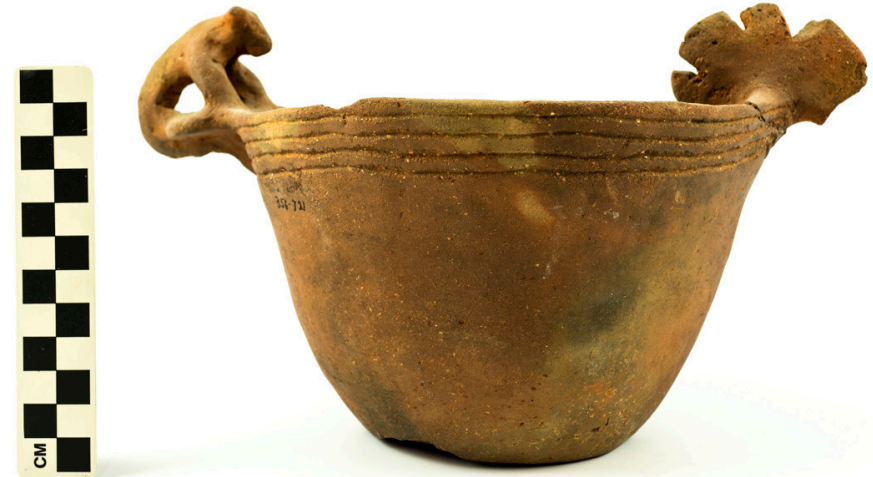

Figure 19. Hood Engraved, var. Allen effigy bowl (41CE12-181) from the Jim P. Allen site (41CE12).

\section{ESTIMATED VOLUME (IN LITERS): 0.7}

DECORATION (INCLUDING MOTIF AND ELEMENTS WHEN APPARENT): The rim has four horizontal engraved lines (Figure 19); these dip down under the attachments for the effigy head and are discontinuous at the tail rider attachment. The effigy head resembles a coxcomb in profile, and this was formed by three deep vertical notches. The tail rider faces inward towards the effigy head, and is a quadruped with two dots for eyes, two small ears, and front and back legs attached to the vessel rim (Figure 19).

PIGMENT USE AND LOCATION ON VESSEL: none

TYPE AND VARIETY [IF KNOWN]: Hood Engraved, var. Allen 


\section{Omer and Otis Hood Site (41CE14)}

There are two Frankston phase cemeteries on the Omer and Otis Hood site (Woolsey 1935e). Cemetery \#1 had 23 burials (18 of which were dug by a UT crew), and dates to sub-phase 2 of the Frankston phase (Kleinschmidt 1982), from ca. A.D. 1480-1560 (e.g., Perttula et al. 2011). Cemetery \#2, an earlier sub-phase 1 burial ground (dating from ca. A.D. 1400-1480), had only three burials, two excavated by Woolsey and crew. Between the two cemeteries there are 118 vessels in the TARL collections, 106 vessels from Cemetery \#1 and 12 vessels from Cemetery \#2. The effigy vessels ( $n=4,3.8$ percent of the Cemetery \#1 vessels) are all from Cemetery \#1.

Ceramic vessel funerary offerings include several varieties of Poynor Engraved carinated bowls and bottles, Hood Engraved effigy bowls (see below), and Hume Engraved bottles. The utility wares are Maydelle Incised jars with and without handles, as well as jars of Bullard Brushed and Killough Pinched.

SITE NO.: 41CE14

FEATURE: Burial AQ-5

VESSEL NO.: 41CE14-33

NON-PLASTICS: grog, hematite, and bone

VESSEL FORM: Effigy bowl with a direct rim and a rounded lip; the effigy head is missing (Figure 20), but the appendage supporting the head is still attached to one side of the vessel, as is the rear appendage supporting the tab tail (Figure 20).

CORE COLOR: Undetermined

WALL THICKNESS: $5.3 \mathrm{~mm}$

INTERIOR SURFACE TREATMENT: smoothed

EXTERIOR SURFACE TREATMENT: burnished

HEIGHT: $7.0 \mathrm{~cm}$

ORIFICE DIAMETER: $12.5 \mathrm{~cm}$

DIAMETER AT BOTTOM OF RIM OR NECK: N/A
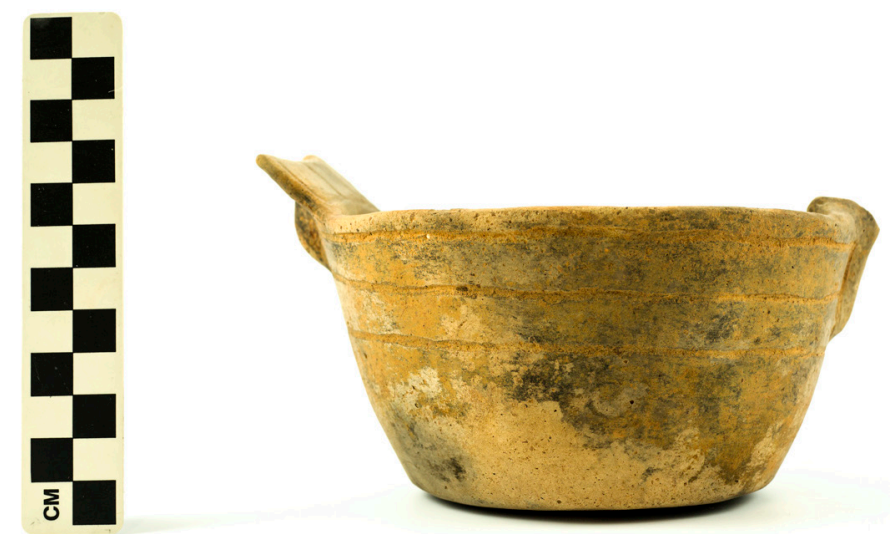

BASE DIAMETER: $9.0 \mathrm{~cm}$

Figure 20. Hood Engraved, var. unspecified effigy vessel (41CE14-33) from the Omer and Otis Hood site (41CE14).

ESTIMATED VOLUME: 0.4 liters

DECORATION: There are three engraved horizontal lines that encircle the vessel, and either run under the appendages or terminate at them (Figure 20). Where the horizontal engraved lines intersect the two vessel appendages, there are three sets of hatched pendant triangles jutting out from the appendages (Figure 20); these pendant triangles on an effigy vessel suggest a typological relationship with Hood Engraved, var. Cook vessels in the upper Neches River basin, although their orientation on the rim is completely different.

TYPE: Hood Engraved, var. unspecified effigy vessel 
SITE NO.: 41CE14

FEATURE: Burial AQ-7

VESSEL NO.: 41CE14-47

NON-PLASTICS: grog

VESSEL FORM: Effigy bowl with a direct rim and a rounded lip; the effigy head has been broken off, but the tab tail appendage remains attached to the rim and the lip (Figure 21)

CORE COLOR: Undetermined

WALL THICKNESS: $6.4 \mathrm{~mm}$

INTERIOR SURFACE TREATMENT: smoothed

EXTERIOR SURFACE TREATMENT: smoothed

HEIGHT: $6.0 \mathrm{~cm}$

ORIFICE DIAMETER: $12.8 \mathrm{~cm}$

DIAMETER AT BOTTOM OF RIM OR NECK: N/A

BASE DIAMETER: $7.9 \mathrm{~cm}$

ESTIMATED VOLUME: 0.3 liters

DECORATION: There are three broad and widely-spaced horizontal engraved lines encircling the upper part of the vessel (Figure 21). The top two horizontal lines dip down in festoons as they proceed under the tab tail appendage, then revert to horizontal lines again.

TYPE: Hood Engraved, var. Hood effigy vessel
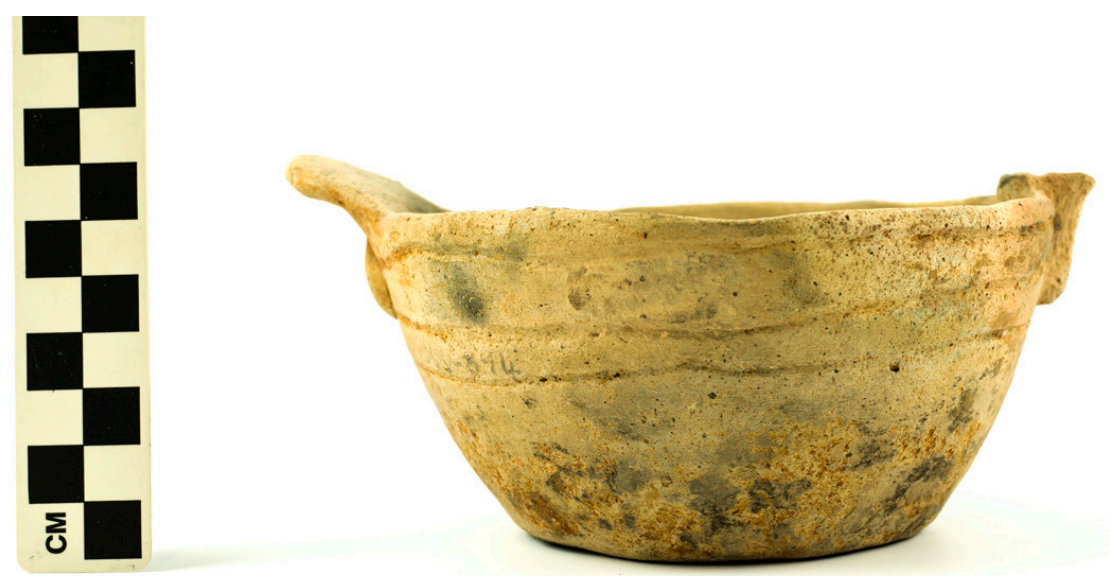

Figure 21. Hood Engraved, var. Hood effigy vessel (41CE14-47)

from the Omer and Otis Hood site (41CE14). 
SITE NO.: 41CE14

FEATURE: Burial AQ-9

VESSEL NO.: 41CE14-77

NON-PLASTICS: bone, grog, and hematite

VESSEL FORM: Effigy bowl with a direct rim and a rounded lip; the effigy head and tab tail appendages have been broken off the vessel (Figure 22)

CORE COLOR: G (fired in a reducing environment but cooled in the open air)

WALL THICKNESS: $4.9 \mathrm{~mm}$

INTERIOR SURFACE TREATMENT: smoothed

EXTERIOR SURFACE TREATMENT: burnished

HEIGHT: $6.0 \mathrm{~cm}$

ORIFICE DIAMETER: $10.3 \mathrm{~cm}$

DIAMETER AT BOTTOM OF RIM OR NECK: N/A

BASE DIAMETER: $6.2 \mathrm{~cm}$

ESTIMATED VOLUME: 0.25 liters

DECORATION: There are three horizontal engraved lines on the vessel rim. The three lines dip down or festoon below the area of the tab tail appendage attachment, but then return to a horizontal orientation on the remainder of the vessel (Figure 22).

TYPE: Hood Engraved, var. Hood effigy bowl
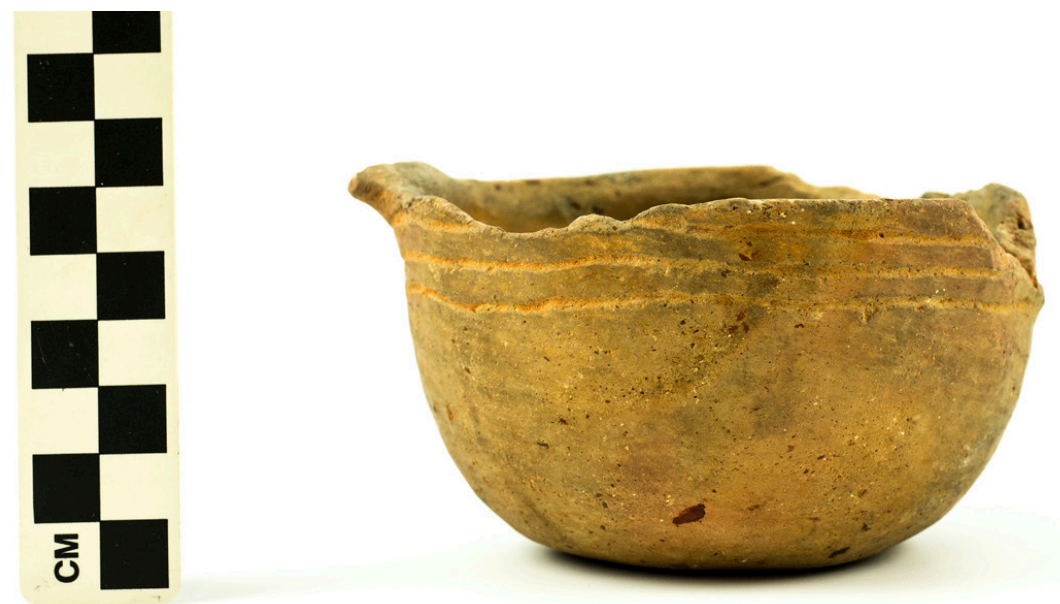

Figure 22. Hood Engraved, var. Hood effigy vessel (41CE14-77) from the Omer and Otis Hood site (41CE14). 
SITE NO.: 41CE14

FEATURE: AQ-13

VESSEL NO.: 41CE14-118

NON-PLASTICS: grog, hematite, and bone

VESSEL FORM: Effigy bowl with a direct rim and a rounded lip; bird effigy head appendage and rear tab tail (4.5 cm wide and $2.5 \mathrm{~mm}$ in length out from the bowl lip) (Figure 23)

CORE COLOR: Undetermined

WALL THICKNESS: $7.0 \mathrm{~mm}$

INTERIOR SURFACE TREATMENT: smoothed

EXTERIOR SURFACE TREATMENT: burnished

HEIGHT: $8.5 \mathrm{~cm}$

ORIFICE DIAMETER: $13.5 \mathrm{~cm}$

DIAMETER AT BOTTOM OF RIM OR NECK: N/A

BASE DIAMETER: $9.0 \mathrm{~cm}$

ESTIMATED VOLUME: 0.5 liters

DECORATION: The rim of the effigy bowl has three broad horizontal engraved lines (Figure 23). These lines are not continuous, as they are absent under the front effigy head as well as under the rear tab tail. Under these appendages, the lines do not meet, but end in small hatched triangles.

TYPE: Hood Engraved, var. Hood effigy vessel

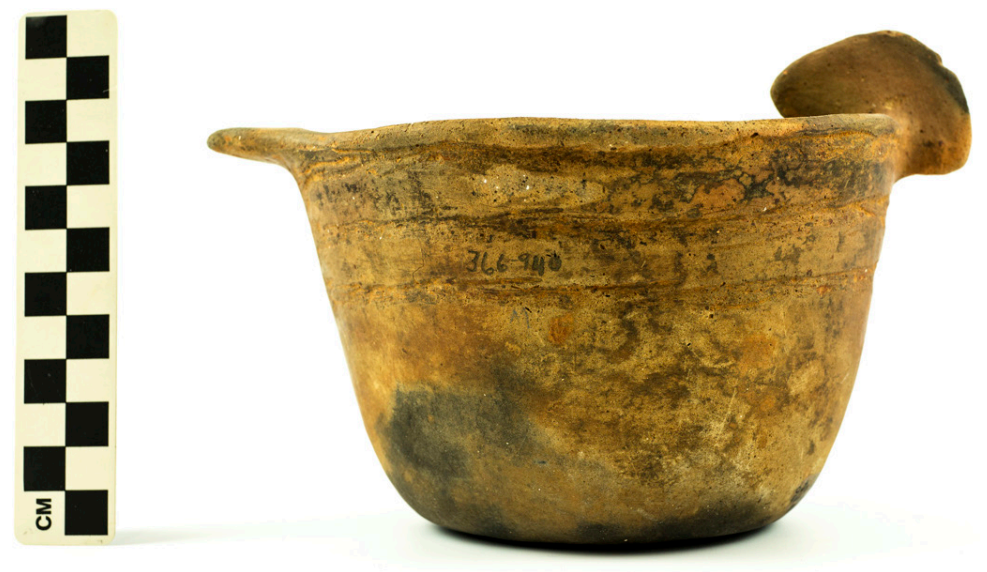

Figure 23. Hood Engraved, var. Hood effigy vessel (41CE14118) from the Omer and Otis Hood site (41CE14). 


\section{E. W. Henry Site (41CE17)}

Excavations by Woolsey (1935f) recovered a number of vessels from 11 Frankston phase, sub-phase 1 burials (dating from ca. A.D. 1400-1480) in the E. W. Henry cemetery. The 35 vessels include 20 carinated bowls, seven bowls, four bottles, and four jars.

The fine ware ceramic vessels from the E. W. Henry site include several varieties of Poynor Engraved carinated bowls and bottles as well as Hood Engraved and Hood Plain effigy bowls. Utility ware vessels from the burials are Bullard Brushed and Maydelle Incised jars.

SITE NO.: 41CE17

FEATURE: Burial AL-5

VESSEL NO:: 41CE17-19

NON-PLASTICS: grog; sandy paste

VESSEL FORM: Effigy bowl with a direct rim and a rounded lip; there is a bird's head effigy (pointing in towards the bowl) at one end of the rim and a tab tail directly opposite (Figure 24)

CORE COLOR: Undetermined; pinkware

WALL THICKNESS: $4.2 \mathrm{~mm}$

INTERIOR SURFACE TREATMENT: none

EXTERIOR SURFACE TREATMENT: smoothed

HEIGHT: $6.8 \mathrm{~cm}$

ORIFICE DIAMETER: $13.3 \mathrm{~cm}$

DIAMETER AT BOTTOM OF RIM OR NECK: N/A

BASE DIAMETER: $7.3 \mathrm{~cm}$
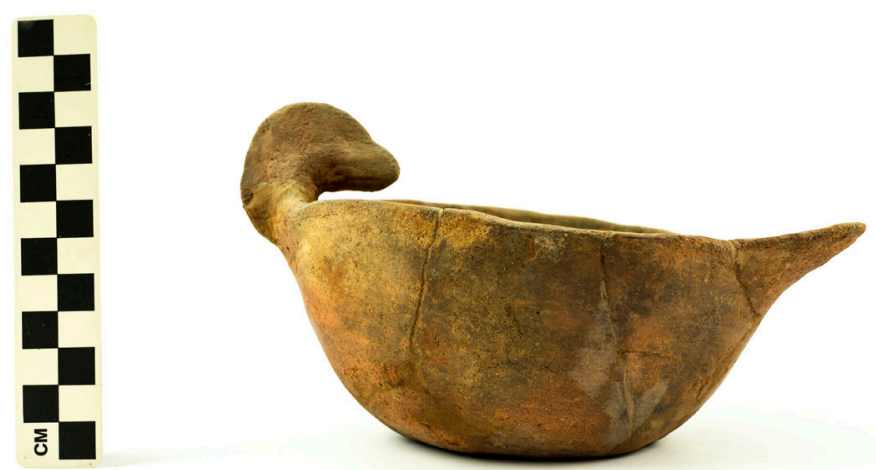

Figure 24. Hood Plain, var. unspecified effigy bowl (41CE17-19) from the E. W. Henry site (41CE17).

ESTIMATED VOLUME: 0.4 liters

DECORATION: plain (Figure 24)

PIGMENT: none

TYPE: Plain effigy bowl, cf. Hood Plain, var. unspecified (see Perttula et al. 2011) 
SITE NO.: 41CE17

FEATURE: Burial AL-7

VESSEL NO.: 41CE17-25

NON-PLASTICS: grog and hematite

VESSEL FORM: Carinated bowl with a direct rim and rounded lip; two sets of two tab tails on the lip (Figure 25)

CORE COLOR: Undetermined

WALL THICKNESS: $5.1 \mathrm{~mm}$

INTERIOR SURFACE TREATMENT: smoothed on the rim

EXTERIOR SURFACE TREATMENT: none

HEIGHT: $6.0 \mathrm{~cm}$

ORIFICE DIAMETER: $11.3 \mathrm{~cm}$

DIAMETER AT BOTTOM OF RIM OR NECK: $11.3 \mathrm{~cm}$

BASE DIAMETER: $6.0 \mathrm{~cm}$

ESTIMATED VOLUME: 0.4 liters

DECORATION: The rim has four rectangular engraved panels defined by two sets of two closely-spaced vertical lines (Figure 25). Within each panel are three concentric semi-circles that are attached to the lower (at the carination) horizontal engraved line of the panel.

TYPE: Poynor Engraved, var. $S$ in the upper Neches River basin (see Perttula et al. 2011)
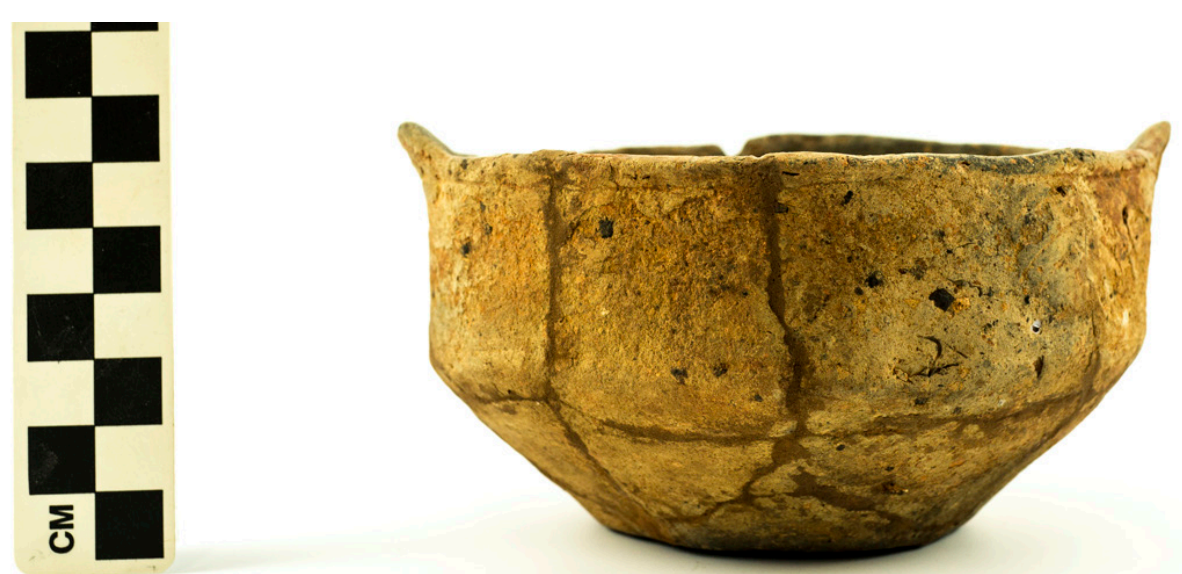

Figure 25. Poynor Engraved, var. $S$ carinated bowl with effigy tab tails from the E. W. Henry site (41CE17). 
SITE NO.: 41CE17

FEATURE: Burial AL-9

VESSEL NO.: 41CE17-31

NON-PLASTICS: grog

VESSEL FORM: Bowl with a direct rim and a flat lip; the effigy head appendage (facing inward) and the large tab tail and lug appendage are at the opposite sides of the vessel (Figure 26).

CORE COLOR: Undetermined

WALL THICKNESS: $6.2 \mathrm{~mm}$

INTERIOR SURFACE TREATMENT: smoothed

EXTERIOR SURFACE TREATMENT: burnished

HEIGHT: $7.5 \mathrm{~cm}$

ORIFICE DIAMETER: $14.3 \mathrm{~cm}$

DIAMETER AT BOTTOM OF RIM OR NECK: N/A

BASE DIAMETER: $9.5 \mathrm{~cm}$

ESTIMATED VOLUME: 0.4 liters

DECORATION: There are three widely-spaced horizontal engraved lines on the upper part of the vessel (Figure 26)

PIGMENT: none

TYPE: Hood Engraved, var. Hood effigy bowl
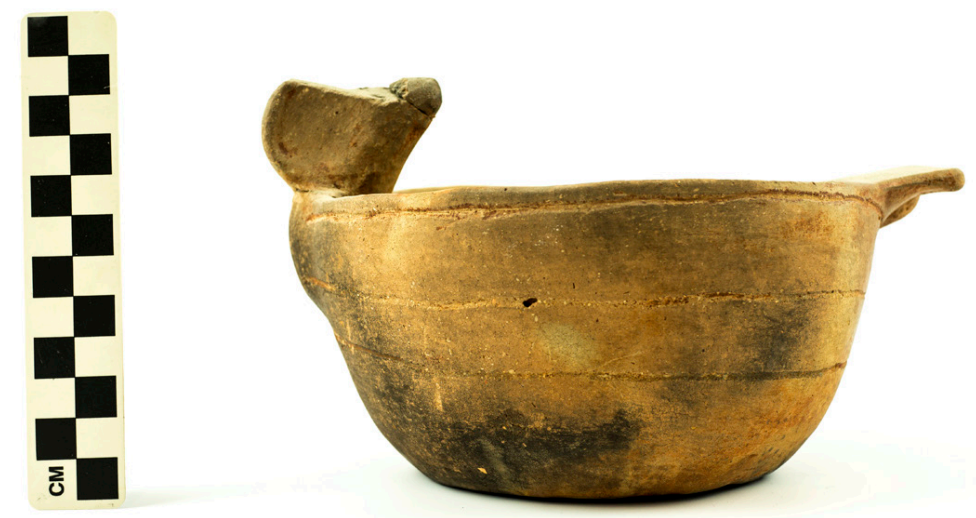

Figure 26. Hood Engraved, var. Hood effigy bowl (41CE1731) from the $E$. W. Henry site. 


\section{Big Cypress Creek Caddo Sites with Effigy Vessels}

Four ancestral Caddo sites in the Big Cypress Creek basin in East Texas have ceramic effigy vessels from burial contexts (see Figure 1). These effigy vessels were funerary offerings in post-A.D. 1500-1550 Titus phase ancestral Caddo burials. At least one of these effigy vessels is a Hood Engraved vessel that was likely obtained in trade/exchange from an upper Neches River Caddo group; the other effigy vessels may represent a local effigy vessel tradition.

\section{H. R. Taylor Site (41HS3)}

The H. R. Taylor site (41HS3) is a large Titus phase community cemetery in the Big Cypress Creek basin. UT archaeologists excavated the cemetery in 1931, which had 71 known burials (Thurmond 1990:Figure 20). A total of 529 ceramic vessels were placed as funerary offerings with the burials, along with elbow pipes, ceramic ear spools, and more than 320 arrow points in quivers; most of the arrow points are Talco and Maud types. The range of decorated vessels from the cemetery (Thurmond 1990:Table 35) suggest the burials were interred after ca. A.D. 1550. The effigy bowls comprise only 0.4 percent of the vessels placed as funerary offerings with the ancestral Caddo burials.

SITE NO.: $41 \mathrm{HS} 3$

FEATURE: Burial A-42. There were 14 ceramic vessels from this burial, including fine wares (two Ripley Engraved, three Taylor Engraved) and utility ware jars (Harleton Appliqued, La Rue Neck Banded, and Cowhide Stamped) (Thurmond 1990:Table 35).

VESSEL NO.: HS3-468

NON-PLASTICS: grog

VESSEL FORM: Bowl

RIM AND LIP FORM: direct rim and rounded lip

CORE COLOR: B (fired and cooled in a reducing or low oxygen environment)

INTERIOR SURFACE COLOR: grayish-brown

EXTERIOR SURFACE COLOR: dark grayish-brown

WALL THICKNESS: rim, $5.1 \mathrm{~mm}$

INTERIOR SURFACE TREATMENT: none

EXTERIOR SURFACE TREATMENT: smoothed

HEIGHT: $5.7 ; 7.6 \mathrm{~cm}$ in height atop the effigy head 
ORIFICE DIAMETER: 12.4

\section{DIAMETER AT BOTTOM OF RIM OR NECK: N/A}

BASE DIAMETER AND SHAPE: 5.6; circular and flat

\section{ESTIMATED VOLUME: 0.28 liters}

DECORATION: There is a horizontal engraved band on the rim, with a series of excised punctations within the band (Figure 27); there are no excised punctations under the effigy head or tab tail attachments.

The effigy has a rounded head with two excised circles for eyes. It is $32 \times 33 \times 14 \mathrm{~mm}$ in height, width, and thickness. The tab tail is split into two halves; overall, the tab tail is $46 \times 35 \times 11.5 \mathrm{~mm}$ in width, length, and thickness. On the top of the tab tail is a horizontal engraved line where the tab tail meets the vessel body, as well as a continuous engraved line that encircles the two halves of the tab tail (Figure 27).

PIGMENT: none

TYPE: Unidentified fine ware
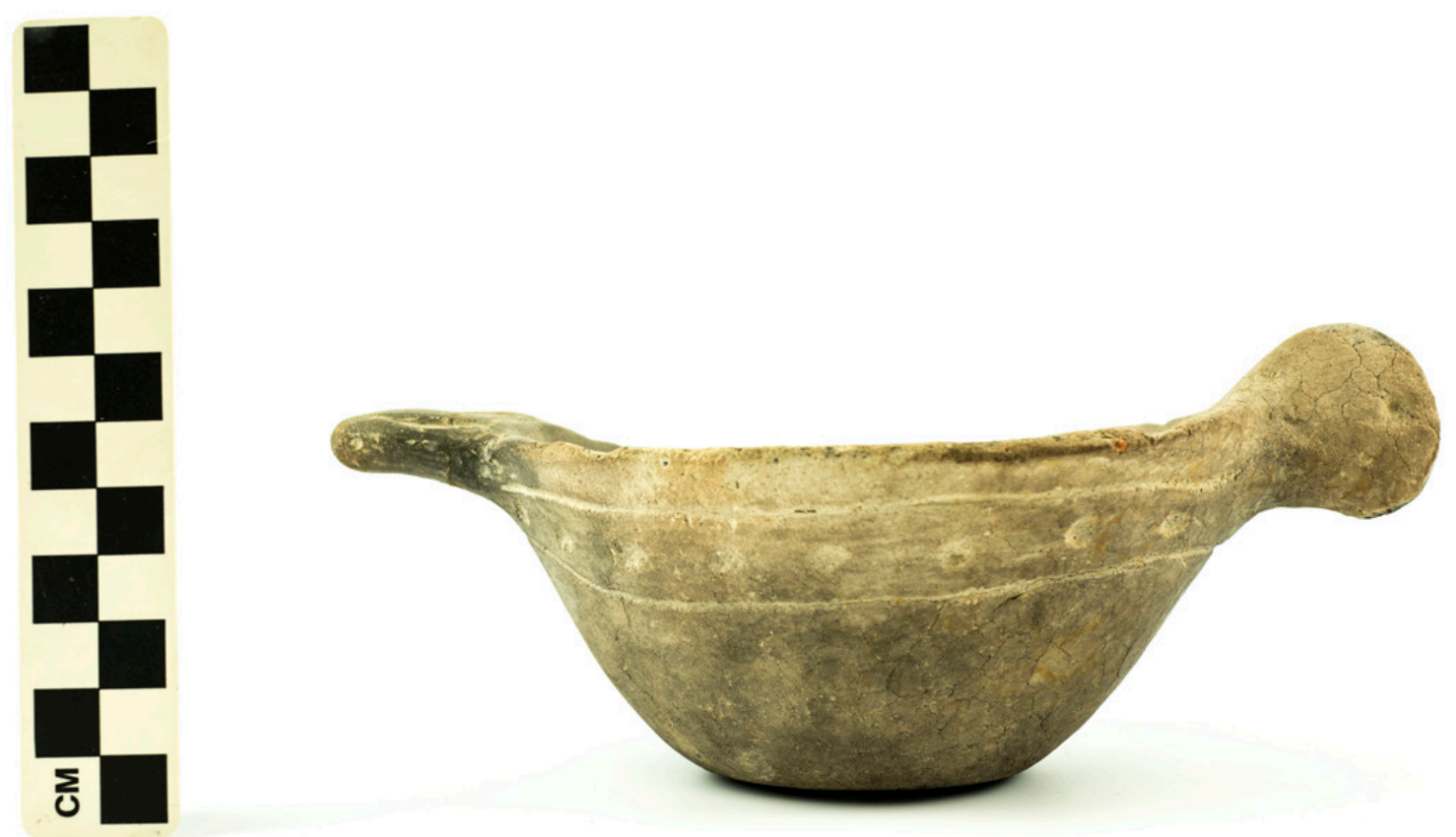

Figure 27. Engraved-punctated effigy bowl (41HS3-468) from the H. R. Taylor site (41HS3). 
SITE NO.: 41HS3

FEATURE: N/A

VESSEL NO.: HS3-731

NON-PLASTICS: grog

VESSEL FORM: Bowl

RIM AND LIP FORM: direct rim and rounded lip

CORE COLOR: F (fired in a reducing environment and cooled in the open air)

INTERIOR SURFACE COLOR: light brown

EXTERIOR SURFACE COLOR: brown; fire clouds on the body and base

WALL THICKNESS: rim, $6.0 \mathrm{~mm}$

INTERIOR SURFACE TREATMENT: none

EXTERIOR SURFACE TREATMENT: smoothed

HEIGHT: $5.5 ; 9.0 \mathrm{~cm}$ in height atop the effigy head

ORIFICE DIAMETER: 13.5

DIAMETER AT BOTTOM OF RIM OR NECK: N/A
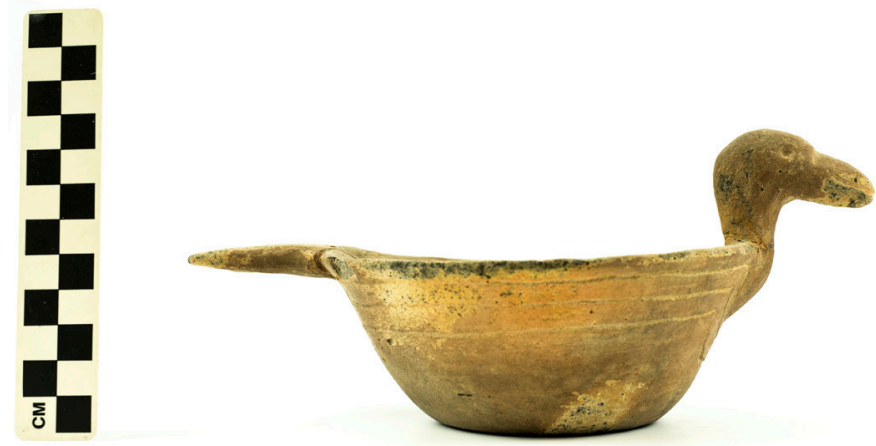

Figure 28. Engraved effigy bowl (41HS3-731) from the H. R. Taylor site (41HS3).

BASE DIAMETER AND SHAPE: 6.5; circular and flat

ESTIMATED VOLUME: 0.30 liters

DECORATION: Three horizontal engraved lines below the vessel rim (Figure 28). The engraved lines dip below the effigy head attachment, but not the tab tail.

The effigy head on this vessel is that of a bird with a rounded head with a long beak. There is an engraved slit for the mouth and two excised circles for the eyes (Figure 28). The effigy head is $47 \times 57 \times 21 \mathrm{~mm}$ in length, height, and width. The tab tail on this vessel is split into two halves. Overall, the tab tail is $52 \times 31 \times$ $10 \mathrm{~mm}$ in length, width, and thickness.

PIGMENT: none

TYPE: Unidentified fine ware 


\section{Thomas B. Caldwell Site (41TT6)}

The Thomas B. Caldwell site is a Late Caddo period Titus phase cemetery near Tankersley Creek in the Big Cypress Creek basin (Thurmond 1990:Figure 23; Fields et al. 2014). Goldschmidt (1934) from UT excavated a cemetery with 10 burials at the site in June 1934.

These burials contained 95 ceramic vessels, 87 arrow points, and a few miscellaneous offerings (a celt, pigment stones, and clay masses) (Thurmond 1990:Table 40). Many of the vessels are of the Ripley Engraved type $(n=43)$, but there are also Wilder Engraved bottles, a Johns Engraved carinated bowl, and a number of utility ware jars ( $n=29)$ - of the types Harleton Appliqued, Pease Brushed-Incised, Killough Pinched, La Rue Neck Banded, and Bullard Brushed - and 10 plain vessels. The frequency of Maud and Talco arrow points in the graves suggest the cemetery may well have been used after ca. A.D. 1500 .

SITE NO.: 41TT6

FEATURE: Burial T-2; the effigy vessel was one of six vessels in Burial 2 (Fields et al. 2014:Figure 7.2).

VESSEL NO.: TT6-42

NON-PLASTICS: grog

VESSEL FORM: Bowl

RIM AND LIP FORM: direct rim and rounded lip

CORE COLOR: $\mathrm{F}$ (fired in a reducing environment and cooled in the open air)

INTERIOR SURFACE COLOR: brown

EXTERIOR SURFACE COLOR: brown; fire clouds on the base, effigy head, and on the tab tail

WALL THICKNESS: rim, $7.3 \mathrm{~mm}$

INTERIOR SURFACE TREATMENT: none

EXTERIOR SURFACE TREATMENT: smoothed
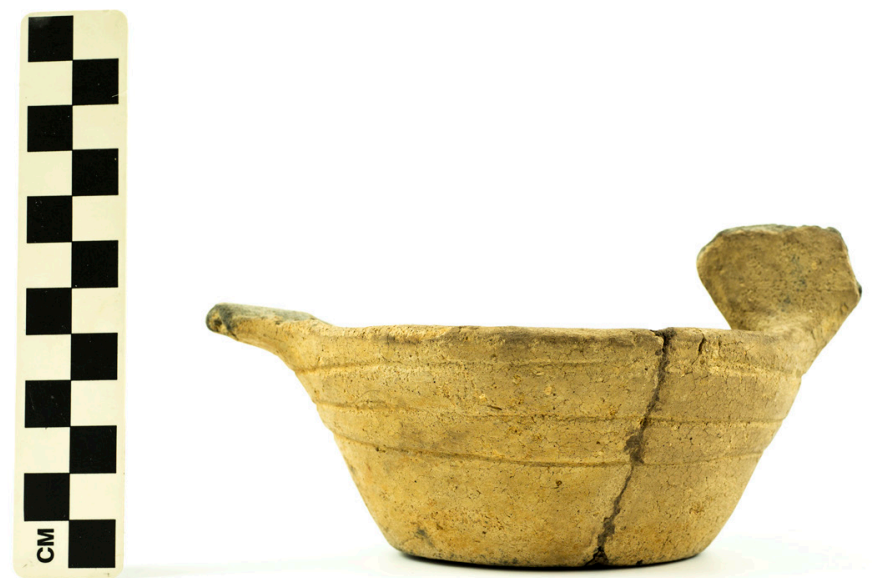

Figure 29. Hood Engraved, var. Hood effigy bowl from the Thomas B. Caldwell site (41TT6).

HEIGHT: 5.5; at least $8.2 \mathrm{~cm}$ in height atop the broken effigy head

ORIFICE DIAMETER: 12.0

DIAMETER AT BOTTOM OF RIM OR NECK: N/A

BASE DIAMETER AND SHAPE: 7.5; circular and flat

ESTIMATED VOLUME: 0.26 liters 
DECORATION: Three are three horizontal engraved lines below the rim (Figure 29). The lines do not dip below either effigy head or tab tail attachments.

The effigy head resembles a bird head, but it is broken. The remnants are 35 x 35 x $10.5 \mathrm{~mm}$ in height, length, and thickness. The tab tail is $53 \times 28 \times 9 \mathrm{~mm}$ in length, width, and thickness.

PIGMENT: none

TYPE: Hood Engraved, var. Hood

\section{W. S. Russell Site (41TT7)}

The W. S. Russell or Russell Brothers Farm site (41TT7) is a Titus phase cemetery on the floodplain of Swauano Creek in the Big Cypress Creek basin (Thurmond 1990:183). It was excavated by UT archaeologists in August and September of 1930 (Gardner 1930), and likely contained as many as 27 ancestral Caddo burials (Thurmond 1990:183); burial pits were difficult to define and Gardner (1930) described the vessels from these burials as caches.

In addition to four effigy bowls, the burials at the W. S. Russell site included 232 other ceramic vessels, as well as elbow pipes, 39 arrow points, one siltstone ear spool, celts, and hematite pigment stones (Thurmond 1990:183). Many of the fine ware vessels are Ripley Engraved carinated bowls and bottles and Wilder Engraved bottles and ollas, along with Harleton Appliqued, Maydelle Incised, Cass Appliqued, Pease Brushed-Incised, and La Rue Neck Banded utility ware jars (Thurmond 1990:183). The frequency of Ripley Engraved, var. McKinney vessels with a pendant triangle motif and Maud and Talco arrow points suggests that many of the graves - and thus the effigy vessels - at the W. S. Russell site date after ca. A.D. 1500-1550.

SITE NO.: $41 \mathrm{TT7}$

FEATURE: N/A

VESSEL NO.: TT7-34

NON-PLASTICS: grog

VESSEL FORM: Bowl

RIM AND LIP FORM: direct rim and flat lip

CORE COLOR: F (fired in a reducing environment and cooled in the open air)

INTERIOR SURFACE COLOR: brown

EXTERIOR SURFACE COLOR: brown; fire clouds on the base

WALL THICKNESS: rim, $7.2 \mathrm{~mm}$

INTERIOR SURFACE TREATMENT: smoothed 
EXTERIOR SURFACE TREATMENT: burnished

HEIGHT: $5.0 ; 7.0 \mathrm{~cm}$ in height atop the effigy head

ORIFICE DIAMETER: 10.7

DIAMETER AT BOTTOM OF RIM OR NECK: N/A

BASE DIAMETER AND SHAPE: 5.4; circular and flat

ESTIMATED VOLUME: 0.21 liters

DECORATION: There are three horizontal engraved lines below the rim; these lines do not dip under the effigy head and tab tail attachments. There is a fourth horizontal engraved line near the vessel base (Figure $30)$.

The effigy head resembles a bird head facing outwards; beneath the head is a small sac, bulge, or node.

The head is not decorated and has no features such as eyes or a mouth (Figure 30). It is $32 \times 39 \times 14 \mathrm{~mm}$ in height, width, and thickness. The tab tail is split into two halves. Overall, the tab tail is $38 \times 30 \times 8 \mathrm{~mm}$ in length, width, and thickness.

PIGMENT: none

TYPE: Unidentified fine ware
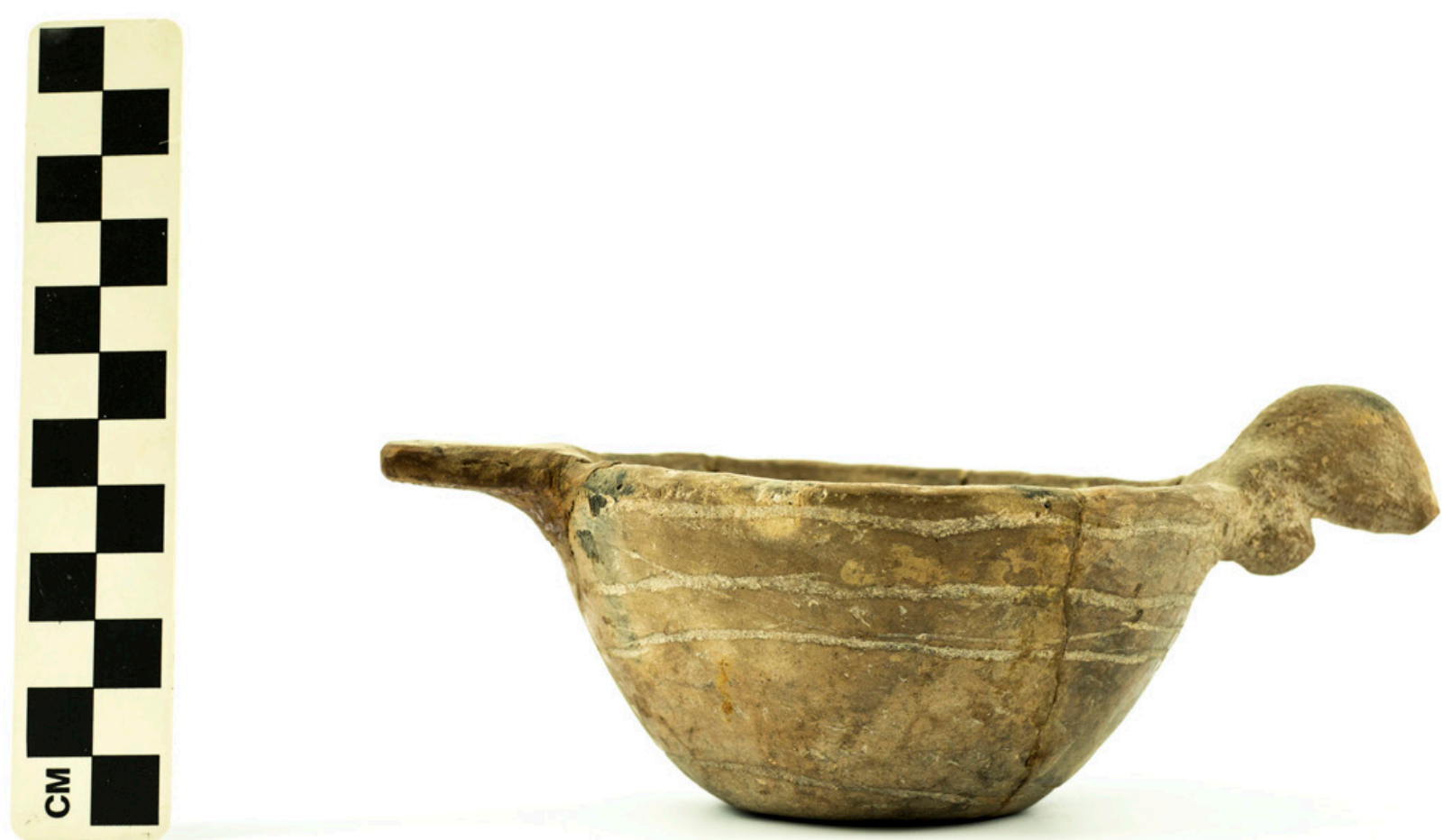

Figure 30. Engraved effigy bowl (41TT7-34) from the W. S. Russell site (41TT7). 
SITE NO.: 41TT7

FEATURE: N/A

VESSEL NO.: TT7-49

NON-PLASTICS: grog

VESSEL FORM: Bowl

RIM AND LIP FORM: direct rim and a flat lip

CORE COLOR: B (fired and cooled in a reducing environment)

INTERIOR SURFACE COLOR: grayish-brown; fire clouds on the rim

EXTERIOR SURFACE COLOR: grayish-brown; fire clouds on the rim, body, and base

WALL THICKNESS: rim, $6.5 \mathrm{~mm}$

INTERIOR SURFACE TREATMENT: smoothed

EXTERIOR SURFACE TREATMENT: burnished

HEIGHT: $5.0 ; 6.7 \mathrm{~cm}$ in height atop the effigy head

ORIFICE DIAMETER: 9.8
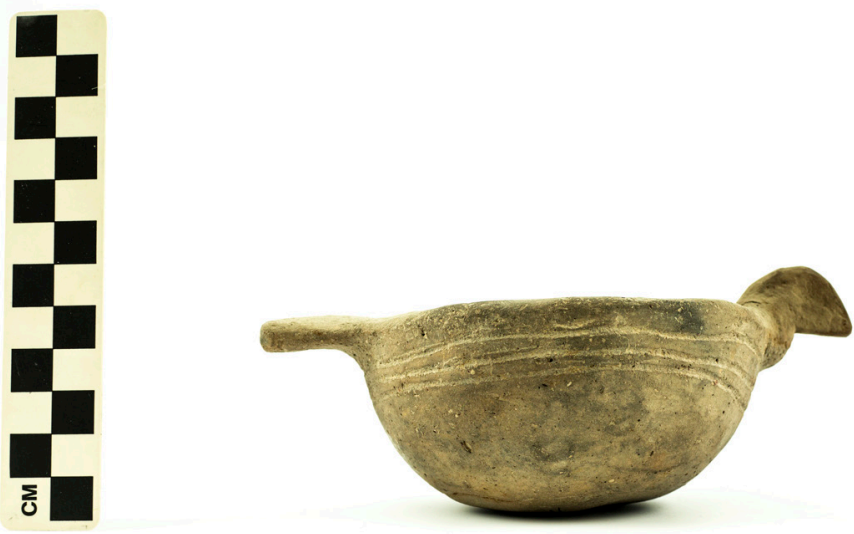

DIAMETER AT BOTTOM OF RIM OR NECK: N/A

Figure 31. Engraved effigy bowl (41TT7-49) from the W.S. Russell site (41TT7).

BASE DIAMETER AND SHAPE: 5.7; circular and round

ESTIMATED VOLUME: 0.20 liters

DECORATION: Three horizontal engraved lines below the rim; the lines dip below the effigy head attachment. The effigy head resembles a bird that is looking outwards; it is undecorated and has no evidence for a mouth or eyes. The bottom of the effigy head appears to have been cut and smoothed to form a straight line; there is also a small sac, bulge, or node below the head (Figure 31). The effigy head is $25 \times 24 \times 9 \mathrm{~mm}$ in height, width, and thickness. The tab tail is split into two halves, but overall, the tab tail is $37 \times 30 \times 8$ mm in length, width, and thickness.

PIGMENT: none

TYPE: Unidentified fine ware 
SITE NO.: 41TT7

FEATURE: N/A

VESSEL NO.: TT7-64

NON-PLASTICS: grog and bone

VESSEL FORM: Bowl

RIM AND LIP FORM: direct rim and rounded lip

CORE COLOR: $\mathrm{G}$ (fired in a reducing environment and cooled in the open air)

INTERIOR SURFACE COLOR: grayish-brown; fire clouds on the rim, body, and base

EXTERIOR SURFACE COLOR: light brown; fire clouds on the body and base

WALL THICKNESS: rim, $7.3 \mathrm{~mm}$

INTERIOR SURFACE TREATMENT: none

EXTERIOR SURFACE TREATMENT: none

HEIGHT: 3.0

ORIFICE DIAMETER: 11.3

DIAMETER AT BOTTOM OF RIM OR NECK: N/A

BASE DIAMETER AND SHAPE: 5.3; circular and flat

ESTIMATED VOLUME: 0.14 liters

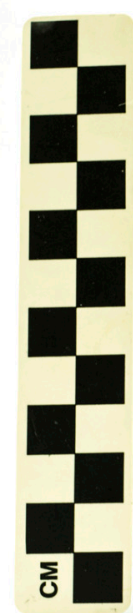

Figure 32. Incised effigy bowl (41TT7-64) from the W. S. Russell site (41TT7).

DECORATION: Two broad horizontal incised lines below the vessel rim (Figure 32). The lines do not dip below the effigy head or tab tail attachments.

The effigy head area has been broken off the vessel. The tab tail area is partially broken, but is $16 \mathrm{x} 11 \mathrm{~mm}$ in width and thickness.

PIGMENT: none

TYPE: Unidentified utility ware 
SITE NO.: 41TT7

FEATURE: N/A

VESSEL NO.: TT7-98b

NON-PLASTICS: grog

VESSEL FORM: Bowl

RIM AND LIP FORM: direct rim and rounded lip

CORE COLOR: F (fired in a reducing environment but cooled in the open air)

INTERIOR SURFACE COLOR: brown; fire clouds on the rim, body, and base

EXTERIOR SURFACE COLOR: brown; fire clouds on the body and base; organic residue on the lower body

WALL THICKNESS: rim, $6.8 \mathrm{~mm}$

INTERIOR SURFACE TREATMENT: smoothed EXTERIOR SURFACE TREATMENT: burnished

HEIGHT: $4.0 ; 6.9 \mathrm{~cm}$ in height atop the effigy head

ORIFICE DIAMETER: 13.5

DIAMETER AT BOTTOM OF RIM OR NECK: N/A

BASE DIAMETER AND SHAPE: 6.3; circular and flat

ESTIMATED VOLUME: 0.22 liters
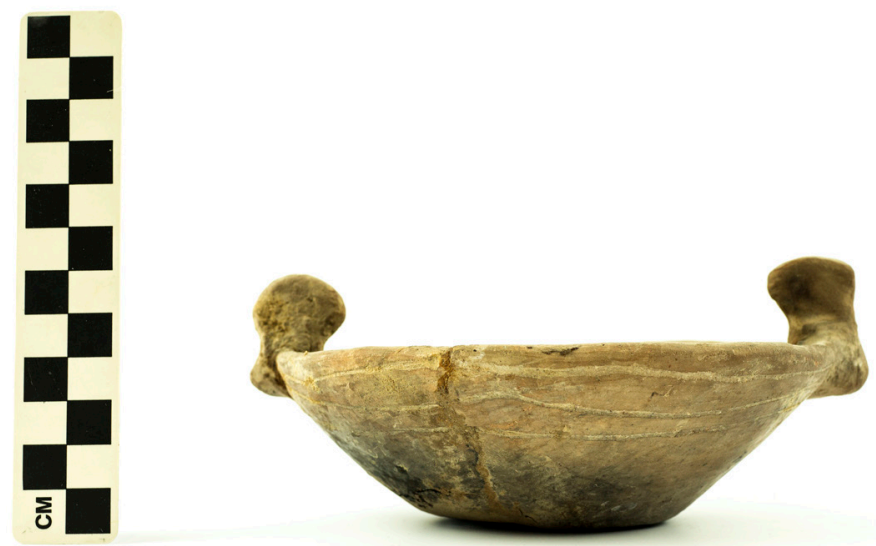

Figure 33. Engraved effigy bowl (41TT7-98b) from the W. S. Russell site (41TT7).

DECORATION: There are three horizontal engraved lines below the vessel rim (Figure 33). The lines do not extend under the effigy attachments.

There are two effigy head attachments at opposing sides of the bowl. Neither has a clear animal or bird shape, but protuberances on them suggest they are both facing inwards towards each other (Figure 33). The effigy heads range from 33-36 $\mathrm{mm}$ in height, 23-24 $\mathrm{mm}$ in width, and 7-9 $\mathrm{mm}$ in thickness.

PIGMENT: none

TYPE: Unidentified fine ware 


\section{J.M. Riley Site (41UR2)}

The J. M. Riley site (41UR2) is a Late Caddo period Titus phase cemetery in the Big Cypress Creek basin. UT archaeologists excavated 18 ancestral Caddo burials at the site in June 1931 (Thurmond 1990:203). These burials contained 179 ceramic vessels, two ceramic pipes, 92 arrow points, and six celts (Thurmond 1990:Table 48).

Many of the ceramic vessel funerary offerings are fine wares: Ripley Engraved carinated bowls and bottles; Taylor Engraved bowls, bottles, and jars; Wilder Engraved bowls, bottles, and jars; and Simms Engraved, Avery Engraved, Belcher Engraved, Bowie Engraved, Bailey Engraved, Hodges Engraved,

and Johns Engraved vessels (Thurmond 1990:Table 48). Utility ware vessels include jars of the following types: Harleton Appliqued, Cass Appliqued, Nash Neck Banded, La Rue Neck Banded, Bullard Brushed, Karnack Brushed-Incised, and Maydelle Incised. The prominence of Ripley Engraved, var. McKinney vessels in the vessel assemblage from the J. M. Riley site, along with vessel types such as Simms Engraved, Belcher Engraved, and Hodges Engraved in several burials, and the occurrence of only Talco arrow points in the burials strongly suggests that the burials at the site date after ca. A.D. 1550 .

SITE NO.: 41UR2

FEATURE: Burial 2; other vessels included as funerary offerings in this burial include Ripley Engraved carinated bowls ( $\mathrm{n}=4)$, a Taylor Engraved olla, Simms Engraved and Avery Engraved bowls, a Wilder Engraved jar, and two Harleton Appliqued jars (Thurmond 1990:Table 48)

VESSEL NO.: UR2-23

NON-PLASTICS: grog

VESSEL FORM: Bowl

RIM AND LIP FORM: direct rim and rounded lip

CORE COLOR: F (fired in a reducing environment and cooled in the open air)

INTERIOR SURFACE COLOR: reddish-brown

EXTERIOR SURFACE COLOR: light brown; fire clouds on the base

WALL THICKNESS: rim, $4.6 \mathrm{~mm}$

INTERIOR SURFACE TREATMENT: smoothed

EXTERIOR SURFACE TREATMENT: burnished

HEIGHT: $4.0 ; 5.7 \mathrm{~cm}$ in height atop the effigy head

ORIFICE DIAMETER: 8.0

DIAMETER AT BOTTOM OF RIM OR NECK: N/A 
BASE DIAMETER AND SHAPE: 5.0; circular and rounded

\section{ESTIMATED VOLUME: 0.13 liters}

DECORATION: Three horizontal engraved lines under the vessel rim. Only the bottom and third horizontal line is continuous around the vessel (Figure 34). The top two lines join and end adjacent to each side of the effigy head and tab tail attachments.

The effigy head resembles a deer with two flaring ears and a long snout. The head has engraved circles for eyes and two engraved slits for the mouth (Figure 34). The tab tail is narrow and nearly horizontal in orientation, measuring $30 \times 12 \times 11 \mathrm{~mm}$ in length, width, and thickness.

PIGMENT: none

TYPE: unidentified fine ware
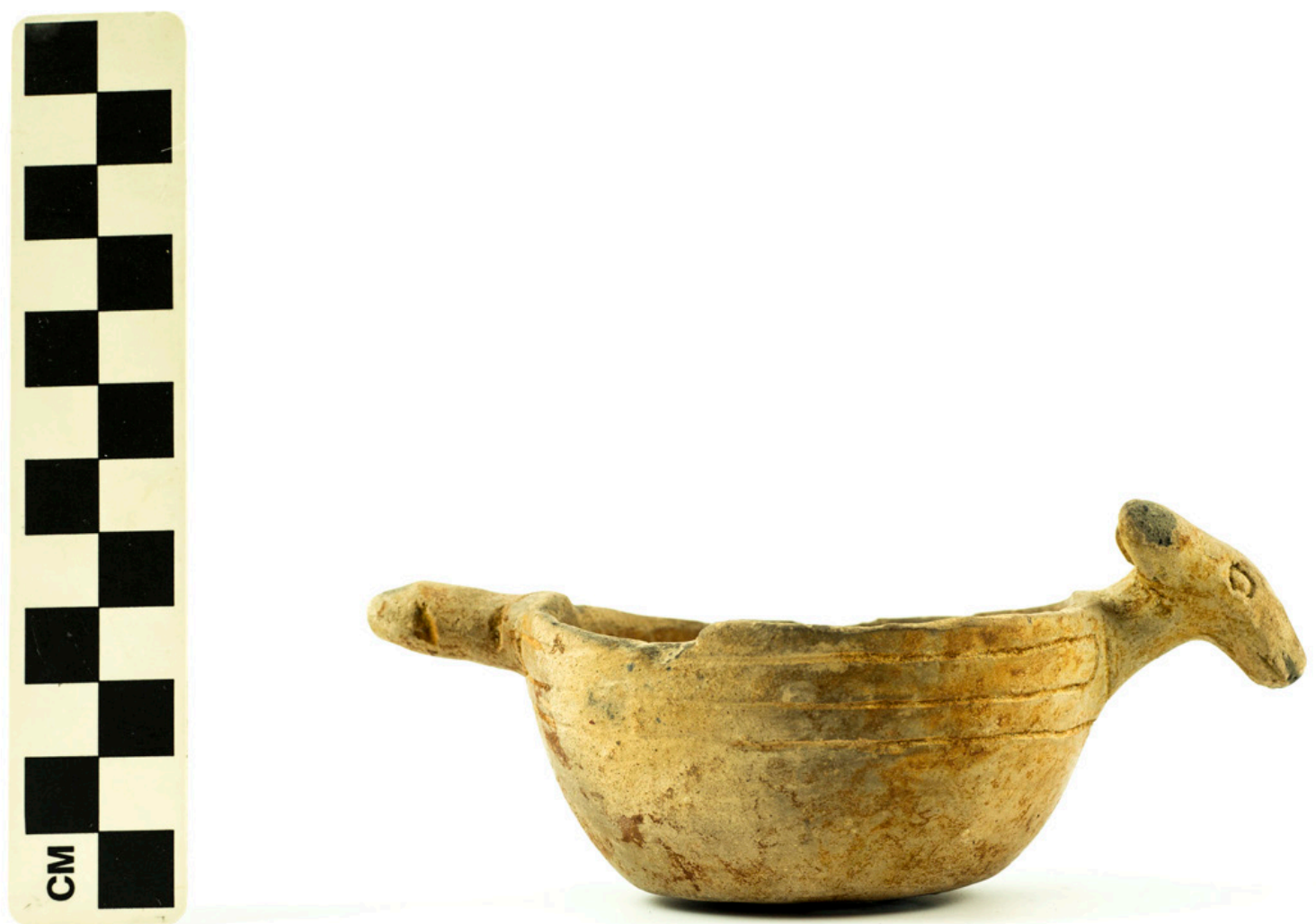

Figure 34. Engraved effigy bowl from the J. M. Riley site (41UR2). 


\section{Red River Basin Caddo Sites with Effigy Vessels}

There are three widely-spaced ancestral Caddo sites in the Red River basin in East Texas that have ceramic effigy vessels (see Figure 1). A fourth site with a bird effigy vessel and a tail rider has been recovered from the Battle site (3LA1) in southwestern Arkansas (Moore 1912:Figure 65; Suhm and Jelks 1962:Plate 24a). These effigy vessels represent a third local tradition of ceramic effigy manufacture, with either plain effigies from the Hatchel and Sanders site, in ca. A.D. 1550-1700 or ca. A.D. 1100-1300 burial contexts, or an elaborately engraved animal effigy bowl from ca. A.D. 900-1100 burial contexts at the Frank Norris site.

\section{Hatchel Site (41BW3)}

The Hatchel site is a large ancestral Caddo mound center and village along an abandoned channel of the Red River. Works Progress Administration excavations at the site in 1938-1939 concentrated on the large temple mound as well as village and burial plots east, south, and west of the temple mound (Perttula 2005, 2014). Village Plot 2 is well to the southwest of the temple mound (Perttula 2014:Figure 3). Burial features in this Village Plot likely date from ca. A.D. 1550-1700, during the latter part of the Texarkana phase (Perttula 2014:77).

SITE NO.: 41BW3

FEATURE: Burial 9, Village Plot 2

VESSEL NO.: BW3-6-6-626 (Field Specimen 24)

NON-PLASTICS: grog

VESSEL FORM: Bowl

RIM AND LIP FORM: direct rim and rounded lip

CORE COLOR: $\mathrm{F}$ (fired in a reducing environment and cooled in the open air)

INTERIOR SURFACE COLOR: brown; fire clouds on the rim and body

EXTERIOR SURFACE COLOR: light brown; fire clouds on the rim, body, and base

WALL THICKNESS: rim, $5.6 \mathrm{~mm}$

INTERIOR SURFACE TREATMENT: smoothed

EXTERIOR SURFACE TREATMENT: smoothed

HEIGHT: $8.5 ; 9.0 \mathrm{~cm}$ at the lip tab

ORIFICE DIAMETER: 14.5

DIAMETER AT BOTTOM OF RIM OR NECK: N/A 
BASE DIAMETER AND SHAPE: 6.6; circular and flat

ESTIMATED VOLUME: 0.49 liters

DECORATION: Plain. The vessel has a lip tab at one end that is $21 \times 8 \mathrm{~mm}$ in width and height. There is no evidence of an effigy head attachment (Figure 35).

PIGMENT: none

TYPE: Unidentified plain ware
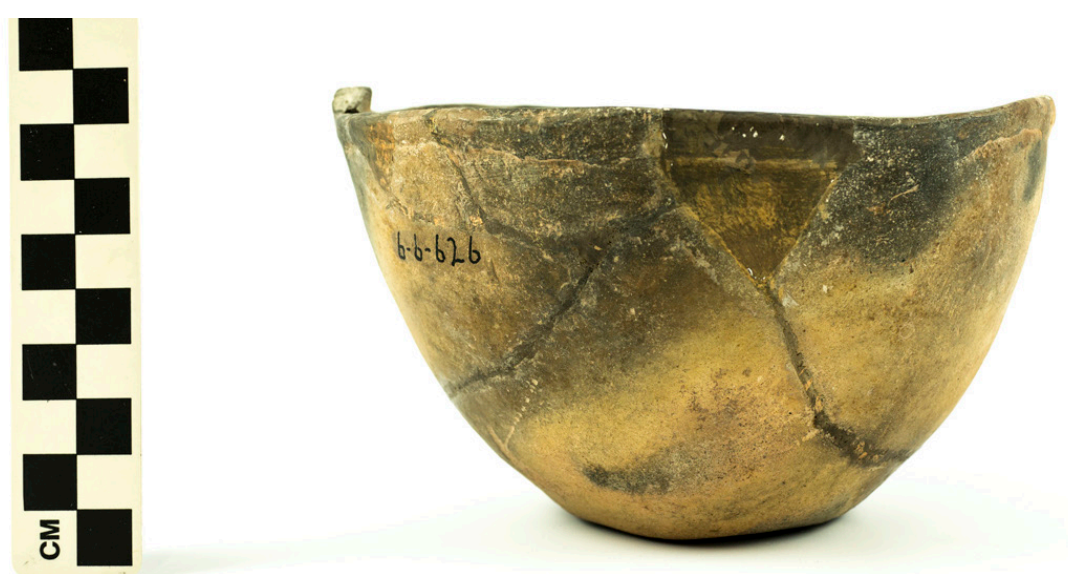

Figure 35. Plain effigy bowl with a tab tail attachment from Village Plot 2 at the Hatchel site (41BW3).

\section{T. M. Sanders Site (41LR2)}

The Sanders site is an important ancestral Caddo mound center and village on the upper Red River, just east of the mouth of Bois d'Arc Creek. Although the Sanders site is not dated by radiocarbon analyses, the general consensus is that the main Caddo occupation took place around ca. A.D. 1100-1300 (see Bruseth 1998), contemporaneous with related sites downstream along the Red River near its confluence with the Kiamichi River, and other sites in the Sabine River basin. The Middle Caddo period component in non-mound contexts is extensive, indicating that there was a substantial population living at the Sanders site and that the site was not simply a mound center and cemetery for the burial of high status individuals in Mound No. 1 (East Mound). The ceramic assemblage that can be associated with this component, which is estimated (roughly) to date from ca. A.D. 1100-1300, includes both the utility wares Canton Incised and Monkstown Fingernail Impressed and the fine wares Sanders Engraved, Sanders Plain, and Maxey Noded Redware. There are also long-stemmed Red River clay pipes, and Alba, Bonham, and Hayes arrow points.

An extensive late 17th-early 18th century Caddo occupation of the Womack phase is also present at the Sanders site, but remains poorly known (Perttula et al. 2015). The material culture assemblage for this component includes plain and decorated elbow pipes along with plain and decorated shell-tempered pottery-including the utility wares Nash Neck Banded and Emory Punctated-Incised and the fine wares Avery Engraved, Hudson Engraved, and Simms Engraved, as well as Clement Redware - and sherds from grogand bone-tempered Womack Engraved vessels; Womack Engraved is the principal fine ware type. 
SITE NO.: 41LR2

FEATURE: N/A; purchased from the landowner in 1931, who excavated several burials from the East Mound (Mound No. 1) at the site prior to the UT archaeological investigation of Middle Caddo period Sanders phase burial features in the mound (Jackson et al. 2000; Perttula et al. 2015).

VESSEL NO.: LR2-18

NON-PLASTICS: grog and bone

VESSEL FORM: Bowl

RIM AND LIP FORM: direct rim and rounded lip

CORE COLOR: F (fired in a reducing environment and cooled in the open air)

INTERIOR SURFACE COLOR: brown; fire clouds on the rim

EXTERIOR SURFACE COLOR: brown; fire clouds on the rim, body, and base

WALL THICKNESS: rim, $6.1 \mathrm{~mm}$

INTERIOR SURFACE TREATMENT: smoothed

EXTERIOR SURFACE TREATMENT: burnished

HEIGHT: 9.5

ORIFICE DIAMETER: 17.5

DIAMETER AT BOTTOM OF RIM OR NECK: N/A

BASE DIAMETER AND SHAPE: 8.5; circular

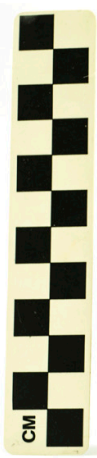

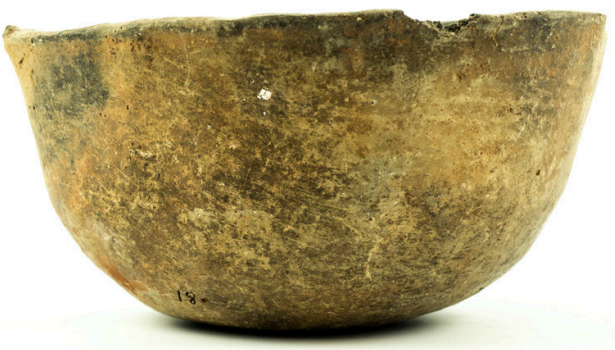

Figure 36. Plain effigy bowl from the T. M. Sanders site (41LR2). and round

ESTIMATED VOLUME: 0.67 liters

DECORATION: Plain. There is no obvious effigy head attachment on the vessel, but the rim in the likely area for an effigy head has been broken away. The tab tail is $24 \mathrm{x} 11 \mathrm{~mm}$ in length and width (Figure 36).

PIGMENT: none

TYPE: Unidentified plain ware 


\section{Frank Norris Site (41RR2)}

The Frank Norris site (41RR2) was recorded by A. M. Woolsey in 1939 as an ancestral Caddo mound center with three mounds on the Red River. Its location, if not washed away by the flood actions of the Red River, suggests that the Frank Norris site, not far to the southeast, may have been part of the much larger Sam Kaufman/Roitsch site (41RR16). This site is a mound center with a large village and numerous cemeteries that have been looted over the years.

The ceramic vessels from the Frank Norris Farm site are readily sorted into two groups based on decorative styles and the use of either grog, bone, or shell as temper during vessel manufacture. The grog$(\mathrm{n}=8)$ and bone-tempered $(\mathrm{n}=1)$ vessels are from Early Caddo Albion phase (ca. A.D. 900-1100) burials (Perttula 2008:Table 1). According to Perttula (2008:322), during this period "a wide variety of finely made ceramics were made by the prehistoric Caddo peoples. Many of the ceramics were quite elaborately decorated." Well-known Albion phase sites in this part of the Red River valley include the Bentsen-Clark site (41RR41) (Banks and Winters 1975) and the Holdeman site (41RR11, Perino 1995). At the Frank Norris Farm site, the vessels from this burial component include the engraved effigy bowl described below, a fingernail punctated jar, a tool punctated jar, a Hickory Engraved beaker and a bottle, one Holly Fine Engraved carinated bowl, a Kiam Incised jar, a Sanders Plain bottle, a Spiro Engraved bottle, and a Spiro Engraved bowl (Perttula 2016).

SITE NO.: 41RR2

FEATURE: N/A

VESSEL NO.: Howard Hampton Collection, \#5. Howard Hampton was an active collector of Caddo ceramics from burials in Red River County, Texas, in the 1930s (e.g., Hampton and Moore 1936), including vessels from 41RR10, just south of the Sam Kaufman/Roitsch site and southwest of the Frank Norris site.

NON-PLASTICS: bone

VESSEL FORM: Bowl

RIM AND LIP FORM: inverted rim and rounded lip

CORE COLOR: B (fired and cooled in a reducing environment)

INTERIOR SURFACE COLOR: black

EXTERIOR SURFACE COLOR: black

WALL THICKNESS: rim, $7.1 \mathrm{~mm}$

INTERIOR SURFACE TREATMENT: none

EXTERIOR SURFACE TREATMENT: smoothed

HEIGHT: 5.7

ORIFICE DIAMETER: 11.0 
DIAMETER AT BOTTOM OF RIM OR NECK: N/A

BASE DIAMETER AND SHAPE: 7.0; circular and rounded

ESTIMATED VOLUME: 0.25 liters

DECORATION: Two sides of the effigy bowl have an engraved motif consisting of vertical cross-hatched and negative oval ladders and two vertical engraved lines that frame a panel with a narrow rectilinear element filled with cross-hatched engraved areas and negative ovals (Figure 37).

The effigy head resembles a beaver head with an engraved slit for the mouth (and the slit ends in a small diamond element), two appliqued nodes for eyes - with a single curvilinear line around the nodes - and an appliqued ridge crest at the top of the head (Figure 37). The tab tail on this vessel has been broken off.

PIGMENT: none

TYPE: unidentified fine ware
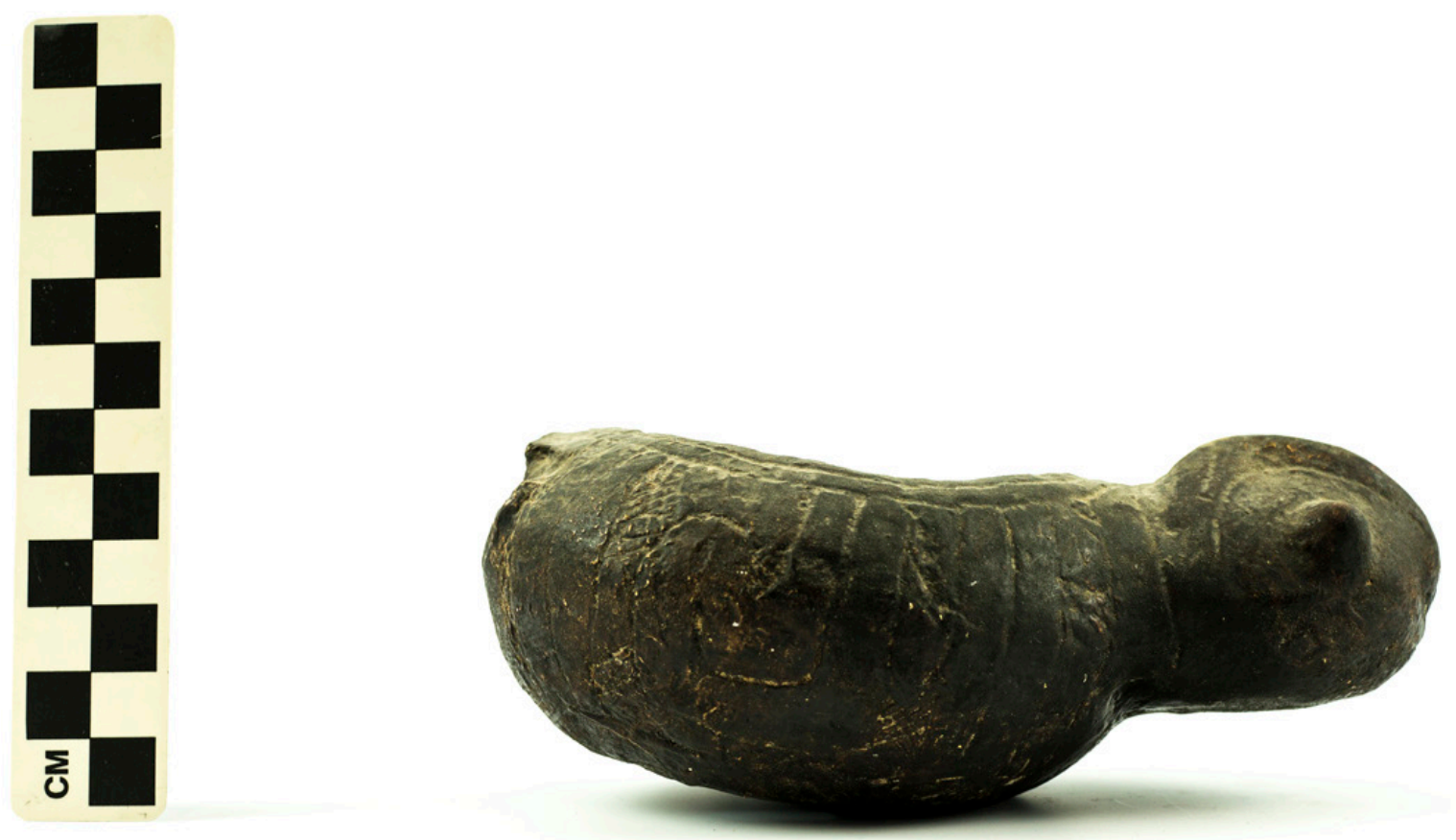

Figure 37. Engraved and appliqued effigy bowl from the Frank Norris site (41RR2). 


\section{Summary and Conclusions}

Our focus in this study has been on ceramic effigy vessels from Caddo sites in East Texas that are in the collections at the Texas Archeological Research Laboratory at The University of Texas at Austin (TARL). Ceramic effigy vessels are a very rare vessel form found on Caddo sites, as they comprise about 1 percent of the more than 3100 Caddo vessels currently in the TARL collections. Specifically, we have documented 35 ceramic effigy vessels in the TARL collections, and these effigy vessels have been found in 16 different sites in East Texas: nine sites in the Upper Neches River basin, four sites in the Big Cypress Creek basin, and three sites in the Red River basin.

Three different effigy bowl shapes have been identified in East Texas Caddo vessel assemblages. The differences primarily resolve around the character of the effigy head (both bird and abstract forms) as well as the nature of any other appendages, such as tab tails and tail riders. The effigy bowls themselves are simple in form, with rounded body wall contours.

With the exception of effigy vessels from Red River Caddo sites, the effigy vessels placed as funerary offerings in East Texas Caddo graves are found in post-A.D. 1400 contexts in Frankston phase (ca. A.D. 1400-1650), Titus phase (ca. A.D. 1430-1680), and Allen phase (ca. A.D. 1680-1830) cemeteries. On Red River sites, the effigy vessels are found singly in ca. A.D. 900-1100, ca. A.D. 1100-1300, or ca. A.D. 1550-1700 contexts. In all, approximately 94 percent of the ceramic effigy vessels in the TARL collections are found in Late Caddo or Historic Caddo period graves in 89 percent of the sites with effigy vessels; most of these vessels are from Upper Neches River Caddo sites, in an area that may be called Effigy Land (Mark Parsons, 2014 personal communication).

These regional and temporal differences in the manufacture and use of ceramic vessels strongly suggests that there was a very considerable diversity among Caddo groups in their cultural practices, beliefs, and world-views about what Caddo adults and children needed in life, and "needed in the other life" (Swanton 1942:205), and that there were cultural, social, and personal boundaries between Caddo groups not regularly crossed by networks of personal and group contacts. The Caddo groups that included ceramic effigy vessels as funerary offerings may have had a basic need for food-serving vessels for corn, atole, a corn gruel pounded into a flour and mixed with water or milk (Chapa and Foster 1997:149, fn 6), and tamales (see Swanton 1942:157-158; Chapa and Foster 1997:149). In 1690, Alonso de Leon noted the use of "pots and casserole dishes," filled with beans, corn, and pinole, made of powdered corn and sugar (Chapa and Foster 1997:150, fn 1). Other vessels, probably bowls and effigy bowls, were reported in historic times to have held incense, body paints/pigments, and corn meal offerings. Perhaps the concentration of ceramic effigy vessels in Upper Neches River basin Caddo sites reflects a unique legacy of feasting behavior, or other cultural activities and beliefs centered around the ritual consumption of food and other materials that was not shared among other Caddo peoples. 


\section{References Cited}

Banks, L. D. and J. Winters

1975 The Bentsen-Clark Site, Red River County, Texas: A Preliminary Report. Special Publication No. 2. Texas Archeological Society, San Antonio.

Brown, J. A.

1996 The Spiro Ceremonial Center. The Archaeology of Arkansas Valley Caddoan Culture in Eastern Oklahoma. 2 Vols. Memoir No. 29. Museum of Anthropology, University of Michigan, Ann Arbor.

Bruseth, J. E.

1998 The Development of Caddoan Polities along the Middle Red River Valley of Eastern Texas and Oklahoma. In The Native History of the Caddo: Their Place in Southeastern Archeology and Ethnohistory, edited by T. K. Perttula and J. E. Bruseth, pp. 47-68. Studies in Archeology 30. Texas Archeological Research Laboratory, The University of Texas at Austin.

Chapa, J. B. and W. C. Foster (editor)

1997 Texas \& Northeastern Mexico, 1630-1690. University of Texas Press, Austin.

Cole, N. M.

1975 Early Historic Caddoan Mortuary Practices in the Upper Neches Drainage, East Texas. Master's thesis, Department of Anthropology, The University of Texas at Austin.

Fields, R. C., V. L. Hatfield, D. Burden, E. F. Gadus, M. C. Wilder, and K. W. Kibler

2014 Testing and Data Recovery Excavations at 11 Native American Archeological Sites along the U.S. Highway 271 Mount Pleasant Relief Route, Titus County, Texas. 2 Vols. Reports of Investigations No. 168. Prewitt and Associates, Inc., Austin.

Gardner, B. B.

1930 Excavation of a Burial Site on W. S. Russell Farm, in Titus County, Texas. MS on file, Texas Archeological Research Laboratory, The University of Texas at Austin.

Goldschmidt, W. R.

1934 Excavation of a Burial Site on Thomas B. Caldwell Plantation in Titus County, Texas. MS on file, Texas Archeological Research Laboratory, The University of Texas at Austin.

Hampton, H. and G. Moore

1936 A Burial Site in Northeastern Red River County. Central Texas Archeologist 2:64-68.

House, J. H.

2003 Gifts of the Great River: Arkansas Effigy Pottery from the Edwin Curtis Collection. Peabody Museum Press, Harvard University, Cambridge, Massachusetts.

Jackson, A. T.

1931 Field Notes, Excavations in Anderson County, Texas, 13 October 1931 to 12 November 1931. MS on file, Texas Archeological Research Laboratory, The University of Texas at Austin.

1935 Notes on Field Work O. L. Ellis Farm on Boggy Creek 6 Miles South of Frankston, Anderson County, Texas, September 26 to September 28, 1935. MS on file, Texas Archeological Research 
Laboratory, The University of Texas at Austin.

Jackson, A. T., M. S. Goldstein, and A. D. Krieger

2000 The 1931 Excavations at the Sanders Site, Lamar County, Texas: Notes on the Fieldwork, Human Osteology, and Ceramics. Archival Series 2. Texas Archeological Research Laboratory, The University of Texas at Austin.

Kleinschmidt, U. K. W.

1982 Review and Analysis of the A. C. Saunders Site, 41AN19, Anderson County, Texas. Master's thesis, Department of Anthropology, The University of Texas at Austin.

Marceaux, P. S.

2011 The Archaeology and Ethnohistory of the Hasinai Caddo: Material Culture and the Course of European Contact. Ph.D. dissertation, Department of Anthropology, The University of Texas at Austin.

Moore, C. B.

1912 Some Aboriginal Sites on Red River. Journal of the Academy of Natural Sciences of Philadelphia 14:481-614.

Perino, G.

1995 The Dan Holdeman Site (41RR11), Red River County, Texas. Journal of Northeast Texas Archaeology 6:3-65.

Perttula, T. K.

2005 1938-1939 WPA Excavations at the Hatchel Site (41BW3) on the Red River in Bowie County, Texas. Southeastern Archaeology 24(2):180-198.

2008 The Archeology of the Roitsch Site (41RR16), an Early to Historic Caddo Period Village on the Red River in Northeast Texas. In Collected Papers from Past Texas Archeological Society Summer Field Schools, edited by T. K. Perttula, pp. 313-628. Special Publication No. 5. Texas Archeological Society, San Antonio.

2014 Archaeological Studies of the Hatchel Site (41BW3) on the Red River in Bowie County, Texas. Special Publication No. 23. Friends of Northeast Texas Archaeology, Pittsburg and Austin.

2015 Diversity in Ancestral Caddo Vessel Forms in East Texas Archaeological Sites. Journal of Northeast Texas Archaeology 56, in press.

2016 The Frank Norris Farm Site (41RR2) on the Red River in East Texas. Journal of Northeast Texas Archaeology 59, in press.

Perttula, T. K., D. B. Kelley, and R. A. Ricklis (assemblers and editors)

2011 Archeological Investigations at the Lang Pasture Site (41AN38) in the Upper Neches River Basin of East Texas. Report No. 129. Texas Department of Transportation, Archeological Studies Program, Environmental Affairs Division, Austin.

Perttula, T. K., B. Nelson, and R. Z. Selden, Jr.

2013 Documentation of Cemeteries and Funerary Offerings from Sites in the Upper Neches River Basin, Anderson, Cherokee, and Smith Counties, Texas. Special Publication No. 26. Friends of Northeast Texas Archaeology, Pittsburg and Austin. 
Perttula, T. K., B. Nelson, M. Walters, and R. Z. Selden Jr.

2015 The Sanders Site (41LR2): A Middle to Historic Caddo Settlement and Mound Center on the Red River in Lamar County, Texas. Journal of Northeast Texas Archaeology 50:1-87.

Suhm, D. A. and E. B. Jelks (editors)

1962 Handbook of Texas Archeology: Type Descriptions. Special Publication No. 1, Texas Archeological Society, and Bulletin No. 4, Texas Memorial Museum, Austin. Reprinted in 2009, Gustav's Library, Davenport, Iowa.

Swanton, J. R.

1942 Source Material on the History and Ethnology of the Caddo Indians. Bulletin 132. Bureau of American Ethnology, Smithsonian Institution, Washington, D.C.

Thurmond, J. P.

1990 Archeology of the Cypress Creek Drainage Basin, Northeastern Texas and Northwestern Louisiana. Studies in Archeology 5. Texas Archeological Research Laboratory, The University of Texas at Austin.

Woolsey, A. M.

1935a Notes on Field Work, E. W. Hackney Farm, 9 Miles Northwest Jacksonville, Cherokee County, November 16 to November 19, 1935. MS on file, Texas Archeological Research Laboratory, The University of Texas at Austin.

1935b Notes on Field Work, Jim P. Allen Farm 7 1/2 Miles Northwest Jacksonville, Cherokee County, October 19-November 4, 1935. MS on file, Texas Archeological Research Laboratory, The University of Texas at Austin.

1935c Notes on Field Work, Jasper Tucker Farm, Mrs. Joe Watkins Owner, 9 Miles Southwest of Frankston, Anderson County, November 20 to November 22, 1935. MS on file, Texas Archeological Research Laboratory, The University of Texas at Austin.

1935d Notes on Field Work, Mrs. J. W. Blackburn Farm, 7 1/2 Miles Northwest of Jacksonville, Cherokee County, October 19, 1935 and October 30-November 4, 1935. MS on file, Texas Archeological Research Laboratory, The University of Texas at Austin.

1935e Notes on Field Work Omer and Otis Hood Farm, 4 1/2 Miles Northwest of Jacksonville, Cherokee County, November 28 to December 7, 1935, Sites No. 1 and 2. MS on file, Texas Archeological Research Laboratory, The University of Texas at Austin.

$1935 f$ Notes on Field Work, E. W. Henry Farm, 7 Miles West of Jacksonville, Cherokee County, Texas. MS on file, Texas Archeological Research Laboratory, The University of Texas at Austin. 
